\title{
Son
}

A novel by

\section{Jennifer Higgie}

\author{
To those who see spirits \\ Human skin \\ For a long time afterwards appears most coarse. \\ Yeats
}

\section{PART TWO}

[For Part one of Son, see PORTAL vol. 1, no. 2 July 2004] 


\section{What Do I draw?}

My pencil has danced of late and would dance even faster if the sun would allow. My hand has become the choreographer of a dance that fills the space above the paper, the area that hovers perpetually between the eyes and the hand. It grabs the shapes and forms handed to me and places them gently on the page, where they rest, sun struck and soporific themselves.

What have I drawn?

The lights that fill me, the ones that pour from windows, from the sky, from eyes. The light that emanates from the sweet candles that soften the moons blow.

The light that slips through the crack in curtains.

The light of the dew that settles on leaves; the glow of broken porcelain, a sliver of glass, a splinter of polished wood. The light that slips from the dim half-light of tea rooms, the markets, the mosaics in the corner of my room. The light that embraces people from behind, in doorways. The light in cloth, in the sweet, dark robes of the women, in the shade cloths, the cloth woven for the sole purpose of keeping out the very substance that gives it form.

The lovely figure of minarets, the precious cargo of secrets in every glance.

The sweep of a gown. Dust on a girl's neck. Variations on a theme of warmth. A sky like an egg shell. Swallowing streets. One donkey and then another. The difference between eyelids, curved eyes, the movement between a mouth and its relationship to the ear. The fall of youthful hair across a pockmarked cheek. A curl on the down of a baby's eyebrow. A rough elbow. The general hint of a belly. The ubiquity of bellies. A women close to birth, her beautiful introspection. A sturdy leg on a delicate body. The bleaching of tones and bones, a scrubbed table.

The dilated pupils of a Priest.

The diluted sugar in a cup.

The colour of honey.

What do I draw?

The violent, yellow sand, the desert. The hypnotic lope of camels.

I draw boats made from hairlines, with flying spars. I draw their rigging, a series of connections, the points between, strung out, thin.

I draw the light constantly denied me.

\section{A Song}

A thin, high song has been coming to me. It increases in volume as we travel. I suspect that this is because I am getting closer to it. I would love to tell Sir Toby of my excitement. Or Sophia. My father. I would like to share it with someone who could hear it too. But I cannot attempt to do so, because it is impossible to write a sound. It is not a song I have ever heard, and quite despite myself, when I first encountered it, it was so clear and so loud I asked Sir Toby if he heard it too.

He said not, and looked at me queerly and talked idiotically of cool drinks and shade.

I shook him off with a clear still eye, and walked further up the worn steps to a place he could not go, and pressed my ear to the stone and listened so hard, I thought my ears would bleed.

It was the sweetest sound and I know it sang for me. I could describe it in an image: imagine, if you will, bright yellow corn framed by a blue sky, the kind of sky you can't believe won't crack beneath the pressure of the sun. Now, imagine moving away from this place and quickly you are somewhere else. A red place, of soft light and whispering, but not of wicked origins. A good, a pure whispering, that makes the listener work to hear it. 
That is a good description of the sounds I heard today.

\section{A Conversation}

We are resting, a rare moment, beneath some more Ruins. I am sitting on a large, warm stone, attempting to draw. The desert is spread before me as simply as a picnic rug, but unfathomable in its combinations. How something so hard and dry can dissolve so gently into an image of water, which in reality is only more sand, is beyond me.

My pencil is fine and sharp. Lines link with other lines, gradually.

Sir Toby is lying, resting, his arms flung out, his face stung with dust and exhaustion. He speaks suddenly, and for once his voice does not sound like a man giving a lesser man a lecture.

It sounds unusually sad.

This is all so old, Isaac. So old.

I am about to ignore his platitude, when something in his attitude stops me. He is still. His eyes are focussed, not roaming, not closed, but staring up at the ancient stones that rise above him. Even his voice is quiet.

This has never happened before.

And so, I answer him.

Yes, Sir Toby, they are old. stillness.

He is deep in some reverie. It is so mysterious, I cannot help but stare at his portly

Isaac?

Sir Toby?

What is the youngest thing you know?

He has thrown me.

Thing, Sir Toby, or person?

Not even a pause, as if he has planned this conversation.

Whatever, Isaac. Just something young.

A slight impatience litters his vowels, as if I, not he, is the obtuse one.

I think hard.

Eggs.

Silence. A loaded silence, which emanates from Sir Toby, and which wishes for more from me. I struggle with the effort of speaking honestly to him.

A drawing just begun.

A sigh of satisfaction from Sir Toby.

So, I think, this is where he was leading. To another dissection of the artistic impulse. I groan. Out loud, without meaning to.

Without sitting up, or looking at me, Sir Toby, speaks, sharply.

Isaac, you are too precious, sometimes, about something that is, after all, only lines rendered by a mortal on what was once something living. I mean paper of course.

I am too astonished to reply.

He continues.

Tell me something else. Something else young. There is too much here that has suffered with age. It is tiring me today.

I think hard.

Spring. Every year, it's young again.

He doesn't reply, but a smile spreads across his face. He looks satisfied.

Spring!

He laughs, stretches, resumes his silence, then sleeps. 
I continue my attempt to capture the wilderness, in fine lines, for his album.

\section{Night Again}

Tonight we sit on our hotel balcony, high above the city.

It is a cool place to drink our brandy after supper. The lights of Alexandria, this mongrel bazaar they call Alexandria, are stretched before us. They look like wet seeds on velvet which shine and dance, but, in truth, today the whole world has danced for me as if it were fit to dance itself into the grave.

Considering its age, I wonder at its lack of exhaustion.

Comfortable on this balcony, the mouths of the city are hushed, its lights wild and abstract. Sir Toby laughs that we are gods in the clouds, as we were in the mountains near the Rhine.

Ah, he sighs, remember how cool and clean the breeze was there?, and sucks on his cheroot with a wistful face, as if he would rather be sitting on a brown bench with a cold ale and a red-cheeked girl than here, where the colours are built to break hearts and inspire homes for homeless words.

His large fingers drum the table beside him. He scratches his knee, as if ready to tear the cloth that covers it.

I do not laugh or sigh with him.

I could weep, the lights of the city are so glorious with their youthful, vivid complexions. And although so small and delicate and far away, it is easy to see now their real scale. Lights to be entered, lights of doorways, of windows, of spaces to hide in. I would have run down the steps and into the throat of the lanes and been swallowed gratefully by them, passed through their portals and frames, but Sir Toby holds me back, with his jocularity and pedantry, his assumption that I will stay by him, that we will retire at a similar hour, eat breakfast together, look at the same things and respond with the same words, share the same thoughts.

He has me by the scruff of the neck, he has me tied to him, like the legs of a donkey are tied together to stop it running.

I am one leg, and he is another, but we are not the same beast. I feel very strongly the need for this fact to be reiterated. I have seen many a donkey hop to find shade.

It is easy to weep for donkeys.

Sir Toby has tied me to him with his generosity, with his money, and even with his affection, he has tied me to him. I have, and this is true, occasionally and wildly looked about me for the nosebag.

To contradict him would take more energy than is worth my while, so I agree with him, for peace. It will have to do for the moment.

I will make pictures of our travels to satiate his appetite for evidence.

I sit quietly beside him and we sip our brandy and talk of Home and archaeology, and I can feel the dust of countless digs settle on our words. I hear our voices from a distance, they are calm and measured. Some small bats fly behind him, he does not notice, I laugh and wave but only to myself, and imagine, even as I speak so calmly, the shadow of a flame on a wall.

The problems of Plato's cave.

Sir Toby believes that he enters the Arab spirit when he puts on their robes, and does not see the girls snigger behind their narrow brown hands. He smokes water pipes with the face of a banker, and considers himself travelled.

There is something sly in his soul that I cannot trust, something not of the surface.

\section{Speaking with Women}


Everything I see was made by a man. I accompany a man in my travels and deal with men in carriages and hotels.

Although motherless, in my old familiar life I am normally surrounded by women. The lack of them has made me hungry for their company, despite the fact that they are secret people to me. They possess an intriguing and unique quality. Men rarely say what is on their minds, but at least you can ask them, however obliquely. Women demand a propriety that I find exhausting. If only you could sit quietly with one, and simply look.

I need to breathe one in, from a narrow distance. Their mystery reassures me about my own.

So, I speak to her, a girl looking at the walls of a church. A young Englishwoman, who has wandered away from her aunt. I know what they are to each other because I have been listening to their conversation. The niece speaks of history, the aunt luncheon. The niece sighs, her eyes drawn the place around her, while the aunt does not listen and expresses a need to sit. The hair of the niece is lemon-pale and her skin is soft and slightly pitted. The hair of the aunt is prickly, her skin slightly flaky.

I like the plum colour of the niece's dress and the awkward angle of her shoulders, which twist slightly, as if a weight is pressing at her side.

As she gazes at the things around her, her small hands clutch a worn guidebook. Her eyes are never still. I would have called her mine then, but it may have startled her. We had not yet exchanged a word, but I know her heart. It is timid, but good, and slightly bored. There is a curiosity in it.

She is someone waiting for something that in all likelihood will never arrive.

It is a difficult thing to do, to choose the words to speak to a woman. So I decide on the simplest ones I can think of, the kind of words that would confuse no one.

Excuse me.

She turns and looks at me. Her eyes are blank, distracted. Polite.

Yes?

I have lost my guide. May I glance at yours?

Certainly. She passes it over.

Here we are in page 67.

I laugh but realise that she does not intend to be funny, and so I duly turn to the aforementioned page and look at the words, which I do not read. Without looking up, I question her.

Have you been here long?

No. A week. We are headed for Thebes.

Ah. Thebes.

I imagine her naked. She is so pale and thin.

I blink hard.

Have you been there?

Yes.

Did it interest you?

Yes

I am warming to my subject when our intimacies are interrupted by a call from the aunt. We turn. The old harridan looks annoyed.

Grace. Come. It is time for lunch.

I hand her back her book. She looks at me. Her eyes, for a moment, do not move from mine.

She coughs a little.

Goodbye. 
I bow. Goodbye.

And then she is gone.

Such finality in so brief an encounter.

How is it possible to hold the attention of a woman?

They are always in the thrall of someone else.

The ruin is empty now and I am hungry.

So I leave.

\section{The Impossibility of Sleep}

My bed is too hot. The sheets slip off my hot skin, as if I were made of polished marble or eggshell. At night I wake and see small lizards fly through the night heat.

The moon is appropriate here. It is not like the moon of Suffolk Street, nor the moon of Chatham. England has a cold moon, a moon with pronounced vowels, a restrained moon. Here the moon is as violent as such a city must demand.

Someone has beaten this moon, so it shines like a bruise, like something recovering, and it bleeds through my window and begs me to press something on it, to cool it.

I dreamt God's fist smashed into bronze and tossed the result away. Tossed into the sky, the moon a failed plate, a repository of fury, a shiny, lost thing.

It comes at me and I cannot bear to look at up. It falls on this terrible, slippery cloth covering my hot body and it is unbearable.

The moon forces me to walk at night, to leave my bed, until I can recognise the moon I used to know, the cold and lovely one that huddles beneath the hot one here.

I can hardly remember the way it used to look, but am reminded when my thoughts have become as calm and as clear as the light it used to offer.

I slip out of our hotel and walk, because walking is the only activity that will still my giddy head, my restless body. The sounds draw me in before the images, the crying and laughing and sighing and wheels and hooves and soft treads of camels, the hints of lives unseen but heard that stain and animate every crack of every Alexandrian breath. The Egyptian night falls suddenly and all objects become shadows. I walk through the midnight heat of the city as if it were a wall I must break down with every step. The heat throbs from every cobblestone, it rises from the black water of the port, it drops like boiling sparks from the immense stars that litter the sky so beautifully and so ominously. I have read that shooting stars are stones thrown by the angels in heaven to drive off evil, eavesdropping djinns. They must be parasitical in their eavesdropping then, never have I seen so many bright flashes across the sky. Heaven must be an active place, curious about its bed linen, the earth. It is difficult, however, to read such strange beauty. A shooting star is as violent and as shocking to witness as a gunfight in a forest at night.

The heat rises from the bowels of the earth. The ground feels as if it has been warmed by hell itself, drugged and burnt by Lucifer. The smells of humans and animals intermingle. Sometimes it is difficult to tell the two apart.

Women of every colour greet me in doorways, copper women, like furnaces, cool lemon coloured women, earth coloured women, gold and black and painted women. They mumble and murmur and entreat me as I pass down narrow streets and I do not give them the pleasure of a response.

This city does not know who or what it is, a temple, a sacrificial altar, a meeting place, a church, a sacred place or a hideously profane one. It changes its mind at every street corner. Copts, Greeks, Jews, Moslems, Turks and Armenians, threadbare camels with hideous grins, humble donkeys, starving cats and mildewed dogs, bejewelled whores and naked saints. The sun and the moon, the sea and the desert live side by side as if their origins were simply 
ingredients for this enormous dish that has produced Alexandria.

Confusion builds in my head like malformed bricks build an unstable house. I try to comprehend such a place, but am too mute and deaf to decipher such complex and, despite the surface of this place, often invisible information that is proffered.

I remain both literally and metaphorically in the dark.

I have become a night man, a moon man, an insomniac.

The sea front offers me some respite, gay as it is with light and the sloping lines of its low horizon. The sea is as smooth as a young girl's cheek, which swells occasionally with something sucked, and sways to a vague plume of music. In this place I can sit and drink mastic after mastic and feel the sea breeze stroke my head like a friend and watch the ships pull in and out and be reassured that whatever the vagaries of my imagination, and however unsettled this place may have made me, there is always the ocean and the leave-taking it offers. Also, the antics of the sailors, sailors from places so far-flung I cannot identify their languages, offer me some amusement. They row ashore from their ships and immediately acquire at least one woman and copious bottles of alcohol and usually interrupt their carousing to cram their mouths and bellies full of squid, cuttlefish or pigeons. I have seen women laughing as they lick the juice from the sailors' unshaven chins, and seen a tongue covered with fish juice enter a painted mouth. These are scenes from Dante or Bosch. How I wish I were a Shakespeare to give them the descriptions, the moral context and the narrative they demand. But I am not. I am simply, and I say this with gorge in my throat, I am simply a scribbler of lines, of outlines and surface.

Like a dilettante, I observe the play but always leave before the final act.

As a writer my observations are impotent. But as an artist, they are simply waiting for my interrogation.

I am distracted by the bricks in every building, distracted by the hand of the person who placed it there. I am crushed by their anonymity.

I pass the open door of a home.

Who plucked those flowers, who crushed the corn?

I need to follow people, to learn who they are.

As the sailors and their whores stumble from tavern to tavern, their voices and songs become louder and louder, their cheeks more violently coloured, their hearts painfully more aggressive and amorous. I have delighted in following certain couples over the course of one night. At times, I have not been able to return to my hotel, despite bone-numbing exhaustion, because I have been compelled to wait for the next instalment, the next kiss, fight or leavetaking. These players in my never ending one act play have become my mental acquaintances, and I have had to remind myself that they do not know me as I know them, as they dance and float past me with their sly floozies, pursued by clouds of aromatic smoke and nauseating perfumes. I have had to hold my hands tight in my lap so as not to greet them as old friends.

I try to draw them before the mastic has become my employer, when my mind is not too overwrought. I find a certain peace in the control my pencil offers me.

I slip back to the hotel before Sir Toby awakes, splash cold water on my face and appear before him for breakfast, pretending I have slept as soundly as he.

Over sweet, warm rolls and coffee, he has started to comment on my pale cheeks and trembling hands.

He has begun to see through my protestations of wellness, and has requested I take a sleeping draught.

He will never learn of my night rambles. I cannot tell him. He may try to make me give them up, but I will not give them up, however tired I might be.

I will never sip his sleeping draught. 
I may never wake up.

\section{Lust}

Sir Toby and I hurry through the streets of Alexandria. Deserted trees huddle together like naked lunatics in the silent squares. I shy away from them in fright.

Please Isaac. We are in a hurry. Hurry.

Poinsettias stain a wall. Fugitive pockets of heat slap me intermittently. The night, and our purpose, has made me acutely aware of shadows.

I do not know why we are in such a hurry. I cannot imagine that whores are particular about time. But Sir Toby is increasingly impatient with me. It is easy for a man with no imagination and no moral imperative to become irritated. If I was not so right and he so wrong I would be irritated with me also.

Sir Toby was loathe to include me in his little outing, but was forced to do so when I interrupted his conversation with Hamid, (a Nubian Sir Toby has employed to show us the Real World of the Arab) and he did not pretend that I had not heard. I heard him as clear as daylight, as anyone would. The trembling undercurrent of his voice makes it clear - he is feeling lascivious.

He has patiently explained to me that the reasons for his visit are purely anthropological.

In that case, Sir Toby, thank you, I would be glad to come. Perhaps I will gain some material. For a painting.

He looks slightly aghast at the thought, and the ensuing expression in his eye makes me aware of his lack of invitation, but an imp has entered my soul and I return his gaze with limpid eyes.

I am filled with curiosity. I am old enough now.

I would like to touch a woman, and, if possible, to forget myself for a while.

I have not, of course, expressed my desires so bluntly to Sir Isaac, but continue simply to articulate my purely academic interest at viewing, at first hand, the contemporary Alexandrian whorehouse.

But Isaac, your father...

My relationship with my father, Sir Toby (and I spoke with almost as much pomposity as he is wont to address me) is a matter between that good gentleman and myself. I am an adult, Sir Toby. If you hadn’t noticed.

He glared at me with his bulbous eyes. He could not retract his conversation. That would negate the angle of his anthropological argument. Imp roared inside me with glee.

All right, Isaac, if you insist. Tonight, at midnight. Hamid will take us.

He coughs and concentrates on a distant spot on a nonexistent wall.

And please, Isaac, do not, despite what you have just said, I ask you especially not to mention this excursion to your father. He may not fully understand our interest. He has never been here. He does not know the (coughs) customs.

I laugh quietly, but am stopped by a fierce look.

Of course not, Sir Toby.

I cannot think of certain sections of his body without shuddering.

He drinks more than is his usual wont tonight. His cheeks are burnished red brown. His hands cannot keep still. He has placed his silkiest, most opulently coloured cravat around his neck and, speaks to me with averted eyes and a touch of fever about Egyptian representations of the cat.

His sentences are pregnant with words he does not speak.

What will happen in this house? 
Before we leave I escape to my room for a moment in a futile bid to gather my thoughts, which, I realise, at this moment, are ungatherable.

The excursion begins with knock on my door. It occurs to me that this journey with Sir Toby could be mapped with the impressions of a thousand different knocks.

Isaac. Are you ready? Time. It is time, boy.

Time. I open my door. He looks away. In the foyer we meet Hamid, who strides ahead, gesturing occasionally with his right hand for us to hurry, hurry.

Faces carved from a material more like stone than flesh pass us, hidden in heavy robes. Some glance at us, dull, shining, gemlike, and murmur obscene guttural sounds in our direction. I glimpse currant eyes in a suet pudding face, a hand clutched to a chest, an earring. The smell of these men reaches out to touch me; they reek of overripe flowers.

Our footsteps sound loud compared to people in robes and slippers. My body feels coarse and heavy, my lips thin and puritanical. I repeat to myself, I am a man in Alexandria walking towards an assignation with a whore.

It is difficult to recognise myself in myself.

I have just realised this: it is not necessary to understand the words these robed men utter, the sounds of the words are articulate enough, full as they are with lust and hate. This is all I need to know. After all, they would not be offering us tea at this late hour. More likely it is their sisters they would serve to us. But why do they murmur and pass on when they must know we cannot respond? What do they want us to do? How would they wish us speak to them?

I have heard the songs of the funeral women, the high-pitched, frightened gurgling that spins around their mouths and eyes. I do not know the words of these songs, but they do not feel as sinister as these sly intimations of cruelty.

Their faces make me long for a candle, or something familiar, light. A pen, perhaps.

Wheels crash over ruts in the road. A man curses and it sounds like spitting. The thin, high-pitched whinnying of a beaten mule, the squeak and jangle of a harness.

Appropriate sounds to accompany such an assignation.

Hamid turns and gestures, hurry, hurry, and glides even faster along the uneven road.

A girl cries out from a shadow and is as suddenly quiet. I pray the hand across her mouth is gentle. Why did she cry out? I slow down to look. Imagine Sophia or Sarah in such a situation. Jane!

But they are a different species.

Sir Toby can hardly contain his anxiety.

Isaac, please, do not look at them, it is not our business. You do not know how angry they might become if they saw us looking. We must hurry.

I am filled with a sudden desperate need to see something that will reveal God to me in these Arabic eyes, a God whose name is different from mine, but who is a God nonetheless. I have questions to ask Him.

Are we different? Would you spurn us? How could we know you? Would you truly burn us in eternity for our lack of love for you? Would you enjoy conversing with someone like me? Would you rather me dead than imaginative?

This city watches us from beneath its eyelids. It is more secretive than sleepy. I can sense the knives under the mattresses. How could a man become righteous or even good in such a city? Perhaps it is easy when the enemy is so tangible.

Sir Augustine. St Augustine. If he were born now would he still want in strength to resist temptation? Would he have visited such a place with Sir Toby? 
Hamid stops suddenly and gestures us towards a narrow door. It is unmarked. He knocks on it, and mumbles a response to the enquiry the door has offered. The door swings open. Sir Toby clears his throat rapidly, three times. Hamid disappears inside. We follow.

A one eyed midget in a turban is blocking our way. In the place of his missing eye, he has a flap of pink, trembling skin. He has crossed his arms across his chest and thick muscles and a large tattoo dominate his shoulders. One tattoo is a picture of a tiger in the act of leaping, and the other is a simple blue circle. I am already in such a state of disorientation that the appearance of this small man seems perfectly logical. I would like to ask him why he chose these particular images for his limbs, but he glares at us out of his one eye, then steps aside to let us through. I do not think he would like to talk with me about himself. I feel as if he has printed our faces on his minds eye. His muscles are shaped for vengeance. He has the appearance of a man in whose robes a vicious implement might be concealed.

The corridor is narrow and long and dimly lit. Hamid walks down it with the air of a man who has walked this way before. The air is thick with incense and some other smell I find hard to place. I imagine I am in the bowels of a strange church, a catacomb, a place for hiding, a place of dreadful dreams. I would like to turn and run back, but cannot.

We reach another door, and the three of us, Hamid, Sir Toby and I, are momentarily pressed against each other, like survivors or escapees, waiting. Then the next door swings open.

My first impression is of a mad pool. Everything is blue. The dim wall is marked with imprint of hundreds of small hands. I am shocked at first. I believe the marks to be from bloody hands, held out while the victims were dragged away. I begin to shake. Then I remember. They are imprints to repel the evil eye. I should find them reassuring but do not. They have left the idea of amputation in my head that, for a moment, I cannot dissolve. The floor is covered with rugs and cushions of quite extraordinary brilliance, the cloth woven from jewels and stars. The red is tempered with ultramarine blue, and yellow ochre and sap green, but the red dominates. Where it touches the other colours it trembles with particular brilliance. Candles glow from hidden points in the wall. And on every cushion reclines, sits up, dances, lies back, giggles a girl, girls I can hardly bring myself to describe they are so young and bizarre to me. Many of the girls are pawed by well-dressed, fattish, soporific men, who do not notice us and hardly seem capable of speech. Some girls sway to the sounds of a large elaborate instrument, which looks like a deformed guitar, played by a sightless old man in a dim corner. His hands move about as if they were controlled by someone else. His eyes roll upwards. I cannot help but think of a marionette and check the ceiling for strings, but there are none. The music is mesmerising. It does not sound like a song with a beginning, middle or an end, but rather like the continuum of something snatched from the air. The girls dance in front of this blind musician, smiling at each other, giggling silently, touching their breasts and mocking his inability to witness their cruelty. Their legs are covered in elaborate silks that sway and shimmer with every movement. Their little breasts are naked beneath transparent beads, and bounce softly up and down as they dance as if they were soap bubbles. They have lined their eyes with charcoal. Some eyes are dull and glazed, some too animated for reason. Their dancing lacks joy, but not contentment. Their hips circle round and round like lazy hoops. Their hands build sculptures out of atmosphere.

These girls are probably the same age as my sisters.

I look away. There is nothing to see but the implication of lust on every surface in every corner, however small. What did I expect? My eyes, quite without my permission, drag my head around the room. It is as if every girl is identical, but within each repetition of a girl there is a sublime and subtle difference. They wriggle and writhe like exotic fish. As they gasp for air, some smile, or look tired, while others kiss men who lie almost prostrate in their 
arms, clutching water pipes. The air is thick with a sweet, sickly smoke.

Sir Toby coughs gently and puts on his anthropological face.

Opium, Isaac. It is best to keep clear of it. If you are unused to it, it may make you sick. It may make you hallucinate apparitions you do not desire.

He speaks with his familiar, lecturing tone, as if his voice might afford this extraordinary scene some degree of normalcy.

Our gazes return to the girls. They are so young that the rouge on their cheeks gives them the appearance of dolls and the fur between their legs is like the fur of newborn kittens. Their hair has been curled, so it frames their little faces like halos. Their lips are painted a vivid, murderous red. Their arms are covered with bracelets that chime and jangle sweetly with their every movement.

An old woman enters from a door and comes up to us. She is limping, grinning and bejewelled. Her face is as soft as an old purse. She holds a limpid, sparkling girl in each hand. I realise Hamid is nowhere to be seen. The girls she holds look at us with boiling little eyes. Sir Toby clears his throat five times. The old hag wordlessly puts a hand in one of ours. Sir Toby is uncommonly silent. I wonder when he will start measuring and interviewing her, but he has been rendered deliciously mute and can only gaze at the exquisite little flower who has taken his hand with the expertise of an ancient courtesan.

I look at mine, this child I am buying, and could momentarily weep with shame and confusion. A tiny pink tongue comes out of her mouth and she licks her lips. She moves close to me and presses herself against my chest. My arms, without my permission, circle her body and reciprocate her embrace. She appears to be quite happy to be given to me. I do not know what is happening. She smells as hot as honey. Sir Toby has disappeared. My eyes are too occupied to see anything but her burning little eyes.

Who set fire to this child that she should burn so?

She reaches up and licks my cheek. Her tongue cuts my flesh like a razor. I can do nothing to stop her licking me. She takes my hand with confidence and leads me to another door, a darker door, and we pass through it. A candle is placed on a candleholder every few inches along this corridor. It is as unreal as any place I have ever seen.

I feel like a flea moving along the neck of a queen.

My girl leads to me to a door and we pass though it, all without a word, and the room she brings me to is small and flickering and filled with the smells of so many flowers I cannot breathe until she pushes me down, onto a deep, dark cushion and places her mouth onto mine, and fills my lungs with air. Her hair falls across my face.

It smells of a heavy oil I do not recognise.

I do not know her name.

Her hair obscures her eyes. I look beneath the painted surface of her face. She has a small crooked mouth, a chipped tooth. A terrible, youthful, inquisitive expression lies deep in her eyes, tempered by something so tired and old I close my eyes, to make it disappear. When I open them, I am confronted with a tiny scar on her earlobe. I look and discover a mole on her neck, and a single white hair, in the midst of all the blackness on her head. I am filled with an overwhelming sense of doubt as to this girl's identity and age. I must see her as God made her. I sit up and she does the same, and puts her small brown hands on my chest. I push her away. We sit on the cushions, and stare at one another. Her eyes do not budge from mine. She licks her lips. I do not respond. I am sure this may be wrong, but would like, at this moment, to suspend such a judgement.

I command her to remove her clothes, her beads, her jewels. At first she does not understand and leans into me, murmuring a low guttural sound like a cat with sly eyes. I push 
her away, again and again. Her eyes dart about the room as if she has lost something. I cannot risk it. I do not know what she may be hiding. I force her to stand up. She stands in front of me as limp as a rabbit skin, her eyes lowered and still. She holds out her arms in front of her as I slide her bracelets from her little wrists.

I undress her. She does not help me. She is just a girl. There is nothing hidden on her but her heart and her thoughts, which she is welcome to. I try the door, and look on the other side of it. No one is there. I return to the girl, who is still standing in the same position, and lie down. She lies beside me. She strokes my head and wraps her narrow brown arms around me. I am then inside her and she undoes me. She is gentle and moans and then whispers something I do not understand. But I do know one thing, and that is that she is on my side. For a moment I am deluded into thinking that I know where that is.

\section{How we Speak of Lust}

The next morning Sir Toby and I are as correct with each other as Bishops at breakfast.

Our mutual formality continues without respite for the next few days, until the memory of our nocturnal visit fades.

I wonder about his experience of that place we went to, and of which, in truth, I am unable to consider in a calm manner. Despite the fact that perfumed, somewhat horrifying images return to me again and again, I resist talking of it to myself.

But I am curious: did Sir Toby treat that girl like a subject, like a specimen, like a curio or a hole, or did he lie beside her and look at her, his eyes on hers, and hers on his, one human to another? We will never speak of it, I know this for a certainty. I am entirely complicit. What happened that night no longer exists as something concrete. It has entered a realm inside me to which I cannot go with anyone else.

I am sure we have begun to believe that we did not go there. It was two other men in a different time.

But we can speak of the sphinx, even though it is far more mysterious and uncommon than lust. There is lust in every moment in every person's heart, acted upon, or frustrated, or incomplete, or violent. It is no different from breathing, yet no one would blush to discuss the mechanics of a breath. I laugh privately and long at this. At the things we allow ourselves to think and not to think. We are master censors of our own minds.

The sphinx is as rare as married virginity. I am not convinced it was built from manpower. It is as unsettling an apparition as any I have witnessed, but also organic, as correct in its shape and form as sand. But even knowing how right it is, I do not understand. It was made for a people who spoke with a different tongue to mine, whose minds were affected by stories I have not heard. It has upset me in all the thoughts I thought I understood so well, that held me upright and made me feel I knew my way around my own head. Travel is, perhaps, useful in that it prompts my own imagination to greater heights, greater exertions, but nonetheless my soul is pervaded with a feeling of unease. My head and heart have become tattered maps, places where the ink has run, yet no one has appeared to clarify the routes this traveller should take. I think of my paintings and am not so convinced now of their fiction. This is a frightening thought. Here, I feel that with every glance in any direction, I take something that does not belong to me. As if my admiration trivialises the most superficial qualities these countries have to offer, namely, their surfaces.

My head is so full of terrible thoughts that at times I have truly doubted my own reason.

I have begun to believe that paintings are not imaginary things, while the world I move through is constructed entirely from shadows. 


\section{Convinced of Pursuit}

I am enjoying the lemon stall when I first notice him. I feel him looking at me, as clearly as when you hear your name spoken in the babble of a crowd.

There is no reason for anyone to be so interested in me, to gaze at me from such close proximity, so why is he there? And why with his face covered? Why does he raise his hands constantly to his face, as if to brush something away? He has no need for lemons, that much is apparent. I do not imagine he is an artist, he somehow appears too distracted in things other than himself. Do men here simply step out to buy lemons? He does not carry himself like a servant. Is he a cook, perhaps?

But why would a cook look so furtive?

I do not mention his presence to Sir Toby, who is exclaiming like a girl over the red of the tomatoes, the deep purple of the peppers. This man has made me indifferent to colour, too preoccupied, too worried about my safety. Is it this mans intention to rob me? Or worse?

Does he wish me dead?

Has someone sent him to spy on me?

I cannot mention his presence to Sir Toby. He would fuss, and this dreadful shadowy man would notice and increase the deception of his sly behaviour. He is a problem I must handle on my own.

It is intolerably hot, and the noises are intense and overwhelming. Sweat pours from the end of my nose. There is a dog howling somewhere, men arguing, women wailing, a bell ringing, someone running fast from something, a million people haggling over a million rotting things.

I would like the noise to be dulled if only for a moment, so I might collect my thoughts and pack them away somewhere safe.

I am so hot I feel dizzy. My blood burns my veins, my feet in their shoes. I feel as though I must have baked my hands in an oven. My skin is wet with heat. I lift the brim of my hat and mop it with my handkerchief.

I would like to stand, just for a moment, in a London downpour without an umbrella, and shiver with cold.

I would like to lie in a cool, still dark room, with my eyes closed and have Sophia bring me some water. But she is too far away, and I am here now, with a problem to attend to.

I am all too aware of the blood pumping through my temples, and through my brain. I do not enjoy the percussion of its passage,

I breathe the thick, slimy air deep into my lungs.

I spend a while choosing a lemon, to test where he will go. He does not move, but stays close to me, without a word.

Perhaps I should speak to him. But that is what he wants, he wants to have me somehow, it will give him a way in. I shall not utter a word in his presence.

I pause. He pauses. I buy lemons, he examines them and chooses one for himself.

Isaac, what on earth do you need with lemons?

Sir Toby by my side, reassuringly bluff. He is genuinely amazed.

For a still life, Sir Toby.

He laughs, relieved and solicitous.

Perhaps, boy, you would like some other fruit, as well?

No, I will do well enough with lemons.

I move through the souk, and pause at a perfume stall. Sir Toby wanders at my side, gazing about him, making small observations, enjoying himself.

The colours of this place Isaac! 
I feel the man near me, his breath on my neck. I cannot turn to look at him. I will not.

We enter a narrow corridor of stalls. The air is suddenly and wonderfully full of flowers, sweet, fresh flowers. We are in the aisle of perfume sellers.

I am momentarily distracted. Sir Toby covers his nose with his kerchief.

Goodness, Isaac. It is a little too much.

I tell him I would like to buy some scent for my sisters. They would enjoy the novelty.

I can see Sophia's dark head bent, sniffing, exclaiming. Her brown eyes laughing with pleasure. A bottle of crushed roses. Some liquid gardenia. A drop of hot patchouli oil.

Sir Toby thinks it a charming idea.

But this strange man is near. I cannot think of scent, or Sophia, or even the possibility of London with this man in my orbit. A group of children materialise, they cluster around us begging, grabbing at our clothes, holding their filthy paws in front of them, palms up towards us with biblical supplication. I brush them away and they return again and again.

Ignore them Isaac, they will get bored. It is the best way. Ignore them.

I cannot.

I ask them politely to leave me be. They will not. I ask them again and again but they feign incomprehension. I shout suddenly at them, and am surprised at the rage in my voice. They scatter like ants before a fire.

Sir Toby turns at my anger and looks at me with anxious eyes. He takes my arm. Without thinking, I shake him off. I am abrupt. Sir Toby looks even more anxious.

Isaac, you must not let these children irritate you so. We will have to deal with many more before our journey is ended. You must learn compassion and detachment.

From the man who stamped on the toes of a child!

He is right, for once, but his lack of memory inspires in me a desire to smash my fist into his face.

I am too hot. I need to be cool. I am too hot.

I will see you up ahead, Isaac. I will be at the carpet stalls.

He is disappointed in me.

I will join you shortly, Sir Toby.

My voice hovers above me. I doubt it belongs to me.

Shopkeepers entreat me, children grab again and again at my clothes, with their incessant demands of baksheesh.

The perfume stall is a tiny, narrow room, filled with hundreds of wooden drawers that stretch high up to the ceiling. An old man, in a long white robe greets me and ushers me in. Without a word he pours me a cup of tea. The angle of his hand as he lifts the cup, the delicacy with which he begins to pour makes me want to weep.

I turn around. I see the man from the lemon stall peering intently in at me. I turn suddenly, back to the perfume shop owner and am overcome with waves of nausea. I put my head between my knees. When I straighten up, the old man is looking at me with an imperturbable expression. He passes me a cup of sweet, fragrant tea and I sip it. It calms me.

The man murmurs words to me I do not understand, but his face is kind and my head cools.

I do not dare to turn around again.

\section{Productivity}

Sir Toby finishes his letter with a flourish, sits back and lights his pipe. Hamid approaches him. He orders a brandy, glances over at me and orders one for me as well. I think he prefers my company slightly drunk. I busy myself with drawing. I draw the chairs, the tiles, the fingernail of moon through the arched window. My pencil flies about like a firefly. I 
am simply the passenger on its back. I cannot talk to Sir Toby at the moment. We stumble about in conversation like peasants wearing clogs trying to make their way through a muddy field. His letters Home are a constant reminder to me of the purpose of our trip. Of why I am here with him and he with me. We are here to see other cultures, to try and understand them and to take Home with us what we have seen, quite despite the fact that we cannot understand anything that anyone has said to us, and quite despite the fact that we are insensitive to these peoples' gods. I know Sir Toby feels the supremacy of his own, and although I struggle against it, I cannot help but feel something in me that is equally patronising to our hosts.

What can Sir Toby' reasons be for such displacement? He professes a passion for travel and is known as a traveller, but all I see in his face as he walks through a foreign place is another little piece of England. When he talks to me, it is as if someone had taken a bell from a village church in Hampshire and rung it from a mosque. His face, the words he speaks, the movement of his body through this foreign place, are so strange, that occasionally they endear me to him. He is as dislocated as I am, and in that, at least, we are comrades.

Whereas I feel uncomfortable when I look on the face of the sphinx, dwarfed by my ignorance of its function, Sir Toby admires the manpower that could create such a thing. He treats history like a book he is keen to finish. He treats these people as if they were no more than subjects for pictures. As if their history stopped at the same point as their skin.

\section{The Desert}

I have been told that the Egyptians believe the desert to be an emptiness populated entirely by the spirits of demons and other grotesque visitants from Eblis, the Moslem Lucifer. I have an urge to see such a desolate place for myself, and not trust to superstition what I might be able to ascertain, or understand, with reason.

(But is it possible, a voice in my head whispers, to see such a devil? His disguises would be a hundredfold more skilful than your imagination.)

Sir Toby is excited at our imminent adventure.

We set out at dawn, Sir Toby, Hamid and I, accompanied by a swathed and taciturn guide whose name I cannot grasp. We are mounted, for once, on noble animals, delicate Arab ponies that look as if they have actually been fed and cared for. Mine is dappled grey and gazes at me with startled eyes. Before I mount, I whisper him endearments, and he nuckers in response and mumbles his soft lips across my palm, licking the salt in my sweat. Despite his Arab origins, I do not doubt he can understand me. He stands as still as a hill as I mount. I lean down and stroke his neck and his ears flicker back and forward, listening, looking all around.

If the devil exists in the desert, this pony will warn me, I am sure of it. He has a wise little dished head, and curved, lovely ears. His eyes are good and watchful. He has fast, fragile legs. I am proud to travel this way, on such an intelligent beast.

Our heads are wrapped in a cloth, Bedouin fashion. I feel slightly absurd, but Sir Toby is as proud as an explorer.

One for the sketch book Isaac! he cries and strikes a heroic pose. I laugh despite myself. The air is still cool and dim, the minarets of the mosques glazed with dew.

Hamid has told me desert people carry the map of the desert in their heads, and orientate themselves at night by the stars.

And by the sun? I ask. He looks at me queerly.

And the sun he replies. 
The only day star, the sun.

We pass beyond the long shady plantations and small lakes until we reach the final gasping borders of cultivation, a border that pockmarks the country with pestilence. It is damp and stinking and humid. Sir Toby rides with one hand, the other holding a handkerchief to his face, his eyes shining above it like hard, glazed stones. Hamid's face is still and forward looking, as if he does not need to breathe unless he chooses to. Our silent guide rides ahead, without ever once looking back at us, without ever once raising his hands to his face.

I refuse to hold anything to my nose, despite Sir Toby entreaties. I will smell this country as closely as I choose to look at it. But it sticks to my throat like tar. The taste of rotting fish coats my tongue.

We trot by a fetid marsh of giant reeds and bulrushes. The sky is as empty as a locked waiting room. The birds have left, or perhaps were never here at all. Fish float dead with white eyes on the vile salt and slime-encrusted surface. The desert, it would seem, likes to greet growth with a dead embrace.

Then we are past it, the ponies treading as delicately as dancers in a bog.

The sky is tinged with lilac. The desert air crowds around us, ebullient, abruptly fresh. Its clean breath slakes and cleanses our gagging throats. Sir Toby stuffs his handkerchief in his pocket and beams at the sky, his face held up to the sun like a sacrificial bowl.

Ah Isaac, the air he cries.

Yes, Sir Toby, the air.

It is all around us. I have never been surrounded by such solid air.

We leave behind a no man's land of arid land cracked with wildflowers and shifting butterflies. Suddenly, the earth changes, and a limitless canvas, a blue expanse of sky undercut with raw pale sand presents itself to us. Our nameless guide breaks, without warning, into a gallop. We follow him joyfully, plunging through the soft dunes with the jerky machinations of wild marionettes. Such a naked expanse should feel like a wasteland but does not. It is not desolate. It is a distilled place, as beautiful as a stream of milk.

Our horses pant and strain for breath, foam pours from their nostrils and their sides heave with the staccato effort of their movement through space. The horizon trembles with mirages. Sweat pours down my face and makes my vision tremble even more. I wonder if my horse can see the mirage. My shirt sticks to my back.

I feel more alive in this desert than I ever have anywhere in my life.

I now know what it means to be a centaur.

We ride to a small oasis, huddled beneath a large unexpected rock. It appears in the heat like a vision and looks to my mind like a dogs head.

Ohh! Ohh! cries Sir Toby.

Three palm trees and a small pool have never been more warmly greeted by a former mayor.

Our horses drink, their flanks heave in and out like bellows and we sit on the cushions Hamid has brought us. Our guide will not look at us, he faces away, across the sand as we nibble on dates and curd cheese and sip sweet, cold tea. Hamid is in a sombre mood. Perhaps he is suspicious of the desert, but if he is he will not tell us. Instead he tells us stories of the smugglers' roads between Algiers and Mecca, highways he says smell of spices and blood, highways of camel tracks that have remained unchanged for hundreds of years despite the shifting dunes. He tells us, his voice hushed in awe, of sheikhs' tents as large as mansions, erected in the middle of the desert, made from cloth woven out of goat hair. He tells us of the Arabic fear of blue eyes and red hair. I look at Sir Toby, at his thinning, greying red hair and watery blue eyes and laugh and laugh. Sir Toby becomes disgruntled and I have to backtrack, 
work hard to alleviate his bad temper. Hamid continues looking down at his crossed feet as he talks. This combination of elements, he murmurs, red hair and blue eyes, are considered evil signs in the Koran, a fact consolidated by the repulsive features of examining angels who are marked by both.

Sir Toby scratches his head nervously and coughs again.

So, Hamid.

Yes Sir?

Do I make you nervous?

No sir. You are English.

Good, good.

Sir Toby is relieved. He does not seem to have noticed that Hamid did not look at him as he spoke, and muttered something in Arabic after his dismissal of Sir Toby' potential to be the embodiment of evil.

More tea Isaac?

Thank you Sir Toby. I will.

Hamid jumps up to check the horses. Our silent guide does not move. Sir Toby and I lie beneath the palm trees and look at the sky.

It is inevitable that we fall asleep in such heat, in such silence. We sleep and we sleep and we sleep. And as I sleep I have a terrible nightmare, but I do not remember what it is that frightens me.

I wake up screaming. Sir Toby appears at my side, slaps my face gently and holds a water bottle to my lips. I think of Michelangelo’s Pieta. I can smell Sir Toby’s English shaving soap. It is almost stranger than my dream to smell such a smell in such a place, in an oasis.

I sit up and am quiet. I cannot speak. I am chilled to my core.

Sir Toby says, enough heat for you my boy, and enough superstitions for one day. No wonder you had a nightmare. Dreadful stories.

He snorts softly.

Hamid looks away, then takes a small phial out of his satchel and brings it to me. Wordlessly he takes the stopper out and holds it my nostrils. The scent of jasmine.

I breathe it in deeply and it calms my nerves.

Our guide is kneeling, looking away from us, muttering incantations.

La Illah Illa Allah. No God but one God.

\section{The Unsent Letter Home}

\section{My Dear Family,}

I must clarify something to you, which I do not believe I have made clear.

When I speak of myself as an artist, you must understand that by artist I mean a person consumed with an enthusiasm too big for containment. The impulse to create something from the interaction of the mind with the world must colour every decision the artist makes. But, conversely, the concept of decision is a fluid one. Often, the artist (the good artist) feels as if there are no decisions, only extreme forms of cause and effect. As for myself, I should really fear to write to any of you about how much I feel when I see all of these treasures that the earth has revealed to me, and that I have only so lately witnessed: cities almost as big and as strange as mountains, or enormous clouds or the deep blue of the sky. In the alleys of these cities, in the chasms and gorges of these mountains, beneath the thick hot scrub of the plains, in the restraint of the desert and in the sparkling and shadowed detachment of the sky: in these places the brightest colours of the symbols of eternity are to be found. 
My enthusiasm betrays me into writing what it would puzzle me to explain: namely, that to be here makes my heart expand, and to dwell amongst such places is to be confronted by thoughts as great and as mysterious as the sand and sky and stone themselves.

I content myself fanning the flames the world has placed before me.

I wait patiently. I know it will not be long before this fire alters forever the shape of the enigmas in my mind.

\section{Cairo}

Decrepit horse cabs pull veiled women through the narrow streets. I do not notice the men. The veils of the women make me curious.

The attentive desert waits in the air, and insinuates itself in particles that wedge in my eyes. My head feels as empty as the rooms of some great abandoned mansion. I am exhausted but cannot sleep. Everyone around me is either moving towards something or someone. I have become inert and can only watch others. I have ceased to participate. Is walking a participation? Or simply a movement through someone else's space?

I no longer care.

This heat has made me torpid.

In the hot noon I wander through the labyrinths of Cairo. Sir Toby sleeps the deep sleep of the self-satisfied. My mind jerks about in my head, my eyes strain to feed it the images it craves. Some are stronger than others: the grimy pharmacies adorned with dried crocodile and stuffed baby elephants fill me with enough images for hours. On the raised floor of the shops sits the sleepy occupant, cross-legged, indifferent, immune to his strange commerce. He smokes a drugged cigarette or a nargileh, as I have heard it called, which droops from his exquisite, sedated hand. I move beyond his blank staring eyes and am surrounded by the cries of the sellers of fruit, coffee and dates. A young boy runs past me shrieking the shout of the sais or runner clearing the street for a carriage, which pursues him like a spurned wife. I am offered solace, treats for a man stupid enough to wonder in the hot, midday sun, sherbets, lemonade or sweetmeats. But I want none of their wares and am curiously indifferent to my strange surrounds.

It is because, and it is hard for me to shape the words, I am lonely.

I do not know why I am here and I have no one to ask.

It is not just for the pictures or the statues or the history, it is for something else I cannot articulate. I am learning too much, yet I have learnt nothing. By nothing, I mean I am learning too much to generalise, and in this revelation I have been made aware of how often I used to express myself with the dogmatism of the ignorant. Now, my head has become too stuffed with images for any conclusions to be drawn about anything apart from one: namely, for some reason, mankind has felt impelled to make marks on surfaces other than themselves.

I do not, despite my immersion in some of the results, exactly know why. And I do not know why we, we being Sir Toby and I, have to move so quickly through so many different places.

I find it difficult to recall the name of anyone I have met in the last month.

Today, however, I watched a woman at a well, and her still, calm face stilled me for a moment. She wore, like many of the women here, a dress of a loose blue shirt with long wide sleeves. Her slim wrists peered like snakes from the mouths of her elegant sleeves. When she moved, every movement jingled to the accompaniment of her silver bracelets. Her hands were tattooed with fine lines and curls. She scratched her chin and laughed and bit her lip. I would have loved to hold her hand and trace the dusty lines of her face with my fingertips! To speak with her about her life here. To enter, somehow, into this environment that is as 
overwhelming as it is impenetrable.

But of course I could not.

I could not.

Her face was touched with a bluish tinge, her headdress decorated with piastres that hung like tiny moons over her eyes. These very same eyes held mine for a moment as she pulled her water towards her, and they were so gentle and good and merry I almost howled with sadness. But I did not. I looked down and when I looked up again she had forgotten me and was laughing with the children playing with pebbles at her feet. Then she moved away and was gone with her heavy load swaying and secure on her head.

A thousand things could have arrested my attention in that scene, but all, except her face, slipped away from me, more unreal than hallucinations. But she remained real and refused, for reasons I cannot begin to understand, to join in that dream pageant around her.

I decided to apply myself to drawing her gentle beauty, which in all truth would not have been displaced in a painting of the Madonna by Raffaele, but, as a result, was engulfed in a situation that only managed to confuse me further. For I at once was involved in something that baffled me, despite its apparent familiarity: I am a foreigner harassed in the marketplace. What happened was this: a menagerie of pompous ruffians emerged from nowhere and overwhelmed me. They banished at once my image of the wellwoman, in fact, momentarily exiled all of my senses, which were replaced with what I can only describe as terror.

How could I not have noticed them before? Were they present when she was? Had I walked by them and not seen them? They were so vivid, my lack of awareness of them now seems to me as if they must have appeared from another world, another dimension, another dream. These splendid savages were clothed in the most magnificent and grubby finery, wild costumes of gorgeous scarlet and blue, framed with their long matted dark hair and sleepy dark complexions. They somehow managed to look at once makeshift and gloriously aristocratic. Noisy shopkeepers, stied in filth, called out to them with joy and respect, while strange and fearless half naked children pulled at their silky legs. Long and vicious sabres, encased in red velvet scabbards, swung murderously on their thighs. They were more like wolves than any men I have ever seen, and all the more frightening in their astonishing resemblance to men. I tried to ignore them, hoping they would not be interested in such a pale and uninteresting specimen as myself, but when I took out my sketch book, all appeared to be forgotten except the wonder my drawing produced, and I was immediately surrounded, not only by these devils in human form, but what felt to me to be the entire population of the marketplace. How their deliciously villainous faces grinned and glowed and exhibited every variety of curiosity. Oh, such expression! Such heads! They closed in on me, and I found myself unable to breathe as easily as I should and so I stood and rapidly packed away my pad and pencils. I then attempted to push myself out of the melee, but they would have none of it and demanded I continue to perform my foreign magic with my pencil. I pushed through them and began to run, but was followed by troops of boys and men, about 50 or 60 in number, all of them incomprehensibly shouting at me. I dived into all sorts of miserable alleys and back ways to avoid them but alas! I might as well have tried to get rid of my own shadow. Finally, I finished up crouched and trembling in the corner of a alley way slum, my hands held in front of me to ward them off, but as they approached, this terrible mob began to hoot and cry and pelt me with husks of corn. Suddenly, quite without my permission, a howl erupted from deep inside me, such a loud, terrifying howl I felt its terror myself, as if I were observing the workings of parts of my mind I had not before witnessed. It was as clever a piece of strategy as any I have initiated. I could have stopped them no more effectively if I had a battering ram and a private army. The mob stopped and was momentarily silent. The eyes looked at me and grew large, their jaws, as one, dropped to their chests. Then, they turned and fled, as if it were 
I who would murder them and not the other way around. All the while they shouted and wailed a strange Arabic song that faded into the cobblestones as they disappeared.

I did not mention this episode to Sir Toby.

\section{Decide to Study the Egyptians}

I must make something of this tiredness. I have a new rule: to read every evening before I retire. I will learn about the significance of these harsh places.

History will translate mute rocks for me.

I have read that the earliest Bible writers were Egyptians, if not by birth, then by spirit and feeling. I read a simple sentence: Moses was found on the Nile.

Moses was found in the bullrushes of the Nile.

These words, read here, among places that are no longer arrangements of letters, take on an entirely different meaning. I realise, very strangely and very suddenly, what it is I am reading. We are headed to where Moses was found. He is not a story. He was found.

What I learnt as a child I must relearn as an adult. I must replace the story with the actual child, with Moses, who once was alive.

I am made acutely aware that since my childhood was replete with fiction, then the fiction must be transformed. The symbolic language of the Egyptians stained every particle of dust. The stardust, the moondust, the earthdust. Everything written in the air, clearly, for everyone to read.

In England I remember the way I looked at the sky. My head would lean back and my face would turn in the right direction, but I would see nothing but a mess of light and stars, indeterminate constellations whose only function was to illuminate the sky and furnish my imagination with props for paintings. My lack of system, my lack of harmony, my sheer ignorance of what our canopy is composed of, has begun to disgust me. I must wheel the constellations into a line in my mind, create order out of abstractions and learn to understand the exact laws of Divine Creation. However, I will try not to be misled by mysteries. But the sun and the moon and the stars are above me now, and demand I take notice of their power.

\section{The Lebanese Mountains}

We have left the cities behind and entered the wilderness.

We travel hard and immensely fast, rising at dawn and riding for eight to ten hours a day. I feel keenly the loss of opportunity for the improvement of my sketches. By the time we reach camp, there is usually very little daylight left in which to do anything but eat and collapse in exhaustion. I try to remember, as I lie with my tired limbs under the stars or in tents or the strange, hospitable home of occasional Sheikhs, the places and people I have seen, to burn them into my memory, to place them there like a drawing in a drawer, so that I will be able, if need be, to pull them out and consult them.

The poor, blighted animals that carry us, either horses or mules, are almost always in a sorry state, and I feel their misery deep in my bones. The sand and heat and sheer mileage we have covered have forced these animals to occasionally drop from beneath us without warning. I have been thrown or fallen and been injured so many times now, I have lost count of my damage, and refuse to acknowledge or look at my cuts or bruises. I have been thrown into streams and down small embankments, but cannot punish the miserable beast whose job it is to carry me: after all, no doubt I would toss them off in the first instance if I were forced to carry them. But at least, for the first time in my life, I am almost a decent horseman. I have 
begun to anticipate the animal's intention before it has had time to think it. I feel my kinship with these beasts. I will not beat them.

I wear a fez tied with two handkerchiefs, one white the other red. I have grown a beard and moustache, and wear a pair of large boots of Russian leather that are so soft and pliable I can shake them off and on with ease. I wear them outside my trousers. They reach half way up my legs. My upper body is adorned with a white blouse that flaps in a satisfying way in the wind.

I would give any thing for my family to appear and for them to witness their brother and son dressed like a wild and romantic vagrant. Sir Toby gains much enjoyment from my appearance, as I do from his. He looks like a plum pudding dressed as a young boy. Is he stouter, or have his clothes grown smaller? I sometimes cannot look at him, for fear of flinging myself off my mount in laughter. But he would be even funnier if he were not so dreadfully stuffed full of himself. I am obliged to pull my scarves low over my ears, in a vain attempt to stem the sound of his self-mythologizing. I long for blinkers to block the failed images of men who cluster around him every time we stop. To witness the value of my companion's title is to witness human sycophancy as its most vile. Grown men simper and oil around him as if he were a Maharajah, and how he laps it up! The world, to Sir Toby is a place built of cream and he is an appalling, corpulent cat.

Witnessing the genuflection such idiocy demands makes me very tired of our planet. I have seen so much disgusting selfishness since I have left England that I am in danger of becoming a misanthrope. But the places we have seen! And having to tolerate the company of Sir Toby has been worth the visions granted to me. They distract my mind so intensely, that I can forget, if only for a moment, who is at my side. Pinara, for example. What a most extraordinary place! A place where men are turned into midgets by the sheer scale of their environment. The atmosphere of unseen presences in this place is almost overwhelming. The wind hits the cliffs with a dreadful hissing moan. The sun beats the earth and stone to no avail: nothing will crumble them.

Gods must coexist uneasily with devils in the crevasses, but despite their proximity neither would be able to find each other in the day or night but in their dreams must eavesdrop on each other's breathing.

The rocks, many hundreds of feet high, tower above the city and their faces are pitted with the infection of a thousand excavations. And nothing, despite their defilement, can compare to the tombs these history thieves have revealed.

From the citadel of Hos we enjoy a view of eternity by the morning sunlight; and as we stand in the ruins of a Roman building, so quickly do our bodies shrink into the dust of time, we fancy ourselves turned into Romans; I admit without compunction that such beauty (although the word is too small) has made me too romantic to be a good companion to myself.

We pass shepherds tending goats, who live in black, camel hair tents, surrounded with staring naked children. We meet one hundred and fifty camels on their way to Smyrna. Their bells clang and tinkle and the drivers are as gay and as bright as colours could ever be. It is difficult to reconcile myself to the idea that here before me are real men, not players in a wondrous circus, or the employees of a giant mechanical doll company. These men can bleed and weep and love! But still, despite their very real flesh, they are as insubstantial as the feathers of exotic parrots.

The plains and the Masicyths range of snow mountains are exquisitely beautiful, too beautiful almost to look at, as if looking with such impoverished eyes might defile such splendour. When they first appeared, I nearly leapt from my skin. Had I died, and been flung 
into heaven?

\section{The Inability to Speak}

Isaac, look!

We have been riding for hours. I am exhausted. I can no longer focus on anything but my hands and the small, curved ears of my pony.

I look up but am blinded by the vibrations of my own tiredness.

I turn to Sir Toby.

What would you like me to look at?

Over there, Isaac. It is really quite wonderful.

He stands in his stirrups and points to a distant peak.

I peer but cannot see anything.

Surely you can see it Isaac?

What?

I do not know how to tell him what it is I cannot see.

I canter away from him and hear his voice fade from my sphere.

I am covered in dust.

Myths

Sir Toby has lent me his book of the stories of Egyptian mythology. Horus and Seth were brothers, who engaged in a violent conflict. In this they bear an uncanny resemblance to Cain and Able. This I find curious. In their fight Horus lost an eye and Seth a testicle but the god Thoth intervened on behalf of Horus and the stolen eye was restored to its owner. After gaining possession of it, Horus presented it to his father, the King Osiris. His eye was meant to protect the king against Seth's violence. But to no avail. Osiris was slain by Seth's madness. In terrible grief the sister and wife of Osiris, Isis and his brother Nephthys searched for their brother. They found him dead.

The thought of finding the body of a sibling quickens and tears at the deepest parts of my heart. If moving through the world is to prepare oneself for some future, unknown grief, then such an image, a concrete image of horror, but built from the flesh of familiar faces is almost too hard to bear.

The imagination is the greatest assassin and the cruellest image giver of all.

Nonetheless, the absurdity of my situation is never lost to me, quite despite the seriousness of what has been revealed. This rotund, shortsighted teasipper is responsible for my introduction to Osiris. He has placed my hand in his, and his in mine. He has pulled my head close to his in order to hear his words all the more clearly.

Sir Toby, unwitting medium, socialite to the stars, deaf man, blind man, unbeliever.

O Heaven speaks, earth trembles. Thou shalt not be cut up, Osiris.

These are stories written to plague dreams.

Speed

We travel too far and too fast for me to sketch. As a result, I am not working hard enough and the thought of such lost opportunity torments me. I must resort to making mental sketches, but sometimes my fury at my idle hands blots them with darkness. We ride so hard, and often through such filth and inconvenience, it is impossible to see around me the things that lie beneath such an infernal rocky country that grows nothing but large stones. Consumed with such a mood, I reach for my history in vain but see nothing but stones. No stories. Simply a brutal, incomprehensible surface.

I may as well be crossing the moon, for all its mysterious connection to who I am. 
When this happens, I cannot speak to anyone.

But now I am awake, or rather have been forced to see beyond my own narrow expectations. We have passed through the wild passes of Engadi by moonlight and I have been shaken to my core, so that I can feel the movement of every drop of blood through my veins, and feel every sliver of bone in me shiver. This place looks to my eyes (my diseased eyes) like the end of the world, but what a finale it is! Extinct craters of volcanoes plunge into the bowels around us, and some of the mountains bend into the most extravagant shapes. The wind howls without a mouth, and the moon beats the earth like a slave-driver. No birds but prehistoric ones. No animals but snakes and lizards that become the colour of rocks or sand at will.

All of them shout at me to conceive of the possibility of shape and substance in the world, shape and substance that gives the sound of the Gods a form. Yes, I will open my mind, I tell the moonlight, and my mind will flourish, because the soil in which it is growing is uncommonly good.

But I cannot reduce the response of my soul to mere words.

This is a response that demands two things of me: action and pictures.

\section{Read}

I read what I have been told is the earliest expression in literature of a belief in life after death.

I read: Recitation: Atum, this Osiris is thy son; thou has caused him to flourish and live. He lives, this King lives; he is not dead, this King is not dead. He has not perished, this King has not perished. If he does not endure, this King does not endure. He endures, this King endures.

I do not understand these words. But they stick in my head like a bee in honey.

\section{Another letter from Home}

Sophia writes me a sad letter and speaks of how she lacks my presence. She tells me how all of my family are lacking me, but I do not believe her. How can they miss what they no longer know?

I search my heart for charity, and find it crouched in a corner of my heart.

I find it in the fact that they do not know that they no longer know me.

She tells me that father speaks of me often, all of my family do, about what it is I could possibly be seeing, or thinking or doing. She writes that when she thinks of the drawings and sketches I will bring home, she can hardly contain her excitement and can only dream of what I am seeing.

See well, she says, and remember everything.

That, I think, is too much of a task for anyone.

She tells me God will keep me well, because He is our God and loves us and we are good and worthy of care.

I do not know whether what she says still holds true.

She wonders if I have seen the Pyramids and the Great Sphinx. She says she does not 
know where I am now, as my letters reach my family from such a long away. My letters make her sad, she says, because they remind her, in such a tangible way, that I am somewhere else.

I wish I could tell her where it is I have come to. Some days I do not know myself.

Sophia does not believe I am telling her everything, and reminds me to share my thoughts with her. My thoughts, she informs me, are more precious to her than any ancient relic.

She does not want her brother to drown or become lost or set upon by brigands.

In London, apparently, nothing is changed. It is colder and the nights longer. The fogs have begun. She has a new coat but little energy. There is much to be seen from our front window, but she is berated by my sisters who chide her for staring and dreaming.

The boys are growing and shout so. Father rarely seems to find time to stay at home.

If I was there, she tells me, she should not lack me.

She orders me again to see well and to draw beautiful pictures, and to speed home to my loving family, but especially to see my loving sister, Sophia.

\section{My Head is a House}

I have come to the realisation that there are at least two versions of me travelling with Sir Toby, each as imaginary and as real as the life inside a painting. Living inside my head is like dwelling in a serene and well-run household, that unfortunately has built into its foundations a few haunted rooms that guests should, at all costs, be discouraged from entering.

Imagine.

Sometimes I am in a calm antechamber eating a sunny breakfast when the sound of music will abruptly begin in a room I cannot locate. Perhaps a piano trio, perhaps a persistent triangle, perhaps the clapping of an intimate audience, who, for some reason, have been issued tickets to be entertained by the deep recesses of their host's mind.

And where is the host to be found? Wandering the lonely corridors, no doubt, looking for a way in. Or a way out.

I can only recognise myself if I look away from who I expect myself to be, a feeling not unlike when as a boy I would search for a particular star and father would say, look away Isaac from the place in the sky you think it to be. You will see it out of the corner of your eye.

And I would.

If I avoid myself at all costs, I might, for a few hours, remain calm.

But.

I find myself gazing at sand and seeing green hills.

I notice hideous faces glaring at me from the faces of sweet young girls.

I see the silhouette of a pig in the mild eyes of a camel.

I lie stuck to my bed, covered in sweat as the mattress breathes and groans beneath me.

I have forgotten the names of my own sisters and my own brothers.

I speak happily, for hours, with my dead mother, whose hand I feel stroke mine, and curse the breath of my father, who is revealed to me as an impostor of the highest order.

I walk in sunlight and feel the hot glare of the moon burn my skin.

I see scorpions the size of men haunting ruins.

I crash into walls I do not see. I pluck poisonous flowers and dream I boil them for tea. I spend hours polishing teaspoons I do not need.

I long to dilute my colours with mirages, to make them hot and trembling. 


\section{Osiris}

I read that Osiris has his helpers and messengers, who execute his command. Apparently these helpers may be objects of terror. This terror is perhaps accounted for by the fact that after being slain by his own son, became a ruler of the kingdom of the dead, the underworld. He rightly threatens those who have sinned against him and whom he condemns as a judge. He is served by demons. They are his executioners.

Osiris is to be dreaded, despite the fact that it was he who was wronged by his child. Perhaps it is a father's wrath that lends his anger such validity.

The world is accustomed to the wrath of fathers. Or, in the case of Christianity, the indifference of the Father who allowed his only son to be murdered.

But Osiris is also a man who has become a God and risen from the dead, and speaks clearly with the moon, which rises every night as he did after he was slain.

Osiris had parents, Nut and Geb. But it was his own son who slew him, who made him a God through his act of violence.

And yet, I do not understand. Osiris would never have become a god if his son had not slain him. But why should a son slay a father? Why should a father be slain to make him a god? He was a man, then a hero, then a god. He has been, perhaps is, every man.

Where is the right and wrong in all of this? Who is right and wrong?

\section{The Solace of Some Words, the Difficulty of Others}

When I read, my sense of disorientation and my fear of instability passes. There is something in these histories that soothes me, challenges me, pulls me up out of chaos and into order. The order of truths that have lasted, dug deep into stones. I lie in a dark cool room and detach myself from such fancies. I say to myself again and again, no. I imagine in my hot head an artist who has taken too much laudanum. I think of this artist inside me, and order him off the premises.

Sometimes it works. Sometimes it doesn't.

And sometimes I am so fascinated by the images this artist conjures for me, I do not want him to leave.

Sir Toby, to whom I have only given the slightest intimation of my troubles, has, for once, been reassuring in the banality of his advice and observations. He has told me of many men who have become lightheaded with the heat.

Sir Toby, lightheaded? I would describe this more as heavy-headed, lump-headed, dream-headed, horror-headed, wrong-headed. I am almost shrill. I hear myself from a long way off, as if I were someone else, an eavesdropper listening to me.

He laughs long and loud and I will put it down to my illness that I detected a note of hysteria in his laughter.

Isaac, Isaac. I warned you of the sun. It is a powerful drug. Your mind will accustom itself, I promise you. You must drink more boiled water, more tea. You must not, on any account, let yourself become dehydrated.

He tells me my illness has been caused, apparently, by a lack of water in the body. But although I have been drinking copious amounts of tea, to counteract my thirst and the apparent aridity of my interior, it has not helped me so much as made me uncomfortably bloated.

It is difficult to locate cause and effect in all of this. 
Imp whispers to me ceaselessly. Who is qualified to say who is sun struck? How can something so golden, so soft, so elusive cause such harm?

The sun hammers away at my head like an argumentative lover. I curse it, wrestle with it, and, during moments of respite soak its light deep into my bones, into my skin, my veins.

But for all its cruelty, I do not want it to leave me.

\section{Buried Among the Ruins of Solitary Limbs}

In ancient Syria, buried among the ruins of solitary limbs, I find a pottery shard.

I hold it to my cheek to visualise it all the better. The earth has delivered it to me, indeed almost tripped me up with its gift, and I would, at all costs, respect such an offering, to find ways of appreciating the earth's generosity. I look at it from all angles and consider how best to appreciate it.

A useless thing, a pottery shard, except as an aide-memoire for a memory I have never had. To think, however, of the brown hands that spun such a simple thing from clay, and placed it in a fire and then filled it with wine or milk or honey, is to breathe a little life into these ransacked and abandoned temples, to glimpse the lives of individuals threaded into a grand narrative like cotton into a carpet.

I sit in the shade of a ruined wall, and ignore Sir Toby's cries as he searches for me, and let the clay whisper to me. I hold it as close to my ears as a seashell.

It smells of dust and sunlight and faintly of piss. It is too disappointing. I cannot, however hard I breathe, smell the wine or the honey or the milk.

I have read: death is simply a phase of tiredness from which it is likely you will awake more refreshed than you ever were. Some Egyptians believed this. Some also believed that blood restores life to the dead.

All dead, or all alive, who held it before me?

\section{Hardship in Palestine}

It is too dry, too cruel, too unfriendly here. Both my skin and that of Sir Toby is as cracked as a riverbed deprived of rain.

I was, for a week, too ill to speak, wracked with the dreadful emptying of my body and a constant thirst that could never be slaked. Our rooms were filthy, the housekeeper slatternly. Sir Toby and I could hardly speak to each other, so depressed were we with our situation.

But I continued to read, when my head had cooled a little, and when my eyes ceased to burn and distort the world it is their job to inform me of. I read how god is magic reflected in the blazing sun. I read that the fruit of the god suits the soil of the living. I have read that we are reminded of cosmic renewal every time we witness the Lord of the west, our sun, sinking before night.

I have come to believe that man must accomplish the work of revelation for himself.

When I could finally walk we ventured into the streets only to be confronted with the slaughter of a dog on the street. Men chatted casually as they hacked at it and for a few seconds it shrieked horribly. Even women and children walked by without giving the poor beast so much as a glance. Finally, its astonished, slow-blinking eyes gave the only indication that it still lived, and then, passing quickly to somewhere else, it died.

The sight forced me back to my room for a few more days.

I am too foreign here even for myself. I see no point in being here, none whatsoever. Sir Toby readily agrees, despite his mania for adventure. 
He promises we shall leave as soon as I am strong enough to travel. He has a friend with a barge, or so he says. One we can drift on, and be waited upon. It is the first time I have heard him say something that has inspired affection in my soul for him.

\section{We Float Together, in Light}

I have never lived in such opulence as this, on the barge of a diplomat, on the Nile, the silent Nile.

I amuse myself play acting. I am Anthony or Hadrian.

But not Osiris. Perhaps I will kneel before him. It is growing in me, the urge to do so. After all, he guards the other world, the one into which we will all eventually pass. It is important to give him his due. I am in his country, on his river, where his own son or brother cast him.

I search the brown water hungrily for traces of his remains, but there is nothing to be seen beneath such an inscrutable surface. Only the counterpoint of drifting, dying, hovering insects. As I look, I am niggled by a paradox: if Osiris is a God to these people, and one to whom the river was his blood, then how can he, in fact, drown in himself?

It is a feeling, however, if not an actuality, I know well.

I read: he swims or floats under thee.

I look and look for him while the Nubian crew slay indifferent chickens for supper and we drift past picturesque hamlets.

I read: death by drowning was blessed by the ancient Egyptians, because it mirrored the death of Osiris.

I read: in the trial that was held in the heavens after the foul murder of Osiris, Osiris is granted eternal life, a vast kingdom, heaven and earth, and the fields of Iaru, the Horite villages, the Sethite villages the cities and the Nomes.

Osiris has become the river, and his son Seth, who slew him, the desert. Nothing grows from Seth. Everything green springs from the bounty of Osiris.

I read: he rode in a barque called the great ship of Eternity and Everlasting.

His wife and sister Isis and his brother Nephthys became his attendant falcons. These birds are the symbols of mourning. Sometimes Isis is a swallow.

Swallows here fly thick and fast around the helm at twilight. They sometimes resemble bats, or thin, exquisite girls, diving through air. I go ashore and walk thorough bean and Doura fields beneath the crazed and courtly antics of Crested Larks and Spurwinged Plovers. Geese and ducks are plentiful. On sand banks large flocks of cranes perch on the rigging or awning rails. Every cluster of mud huts honours the pigeons. It is customary to place large earthenware jars with protruding branches outside homes for the birds to sit on.

The villages look like deserted ant hills. Conglomerations of rubbish huddle around their extremities, almost lost among the occasional belt of palms that surrounds them. Coloured plates and saucers hang from the doors to avert the gaze of the evil eye.

This is a hopeful land, a place for birds to land.

I read: The bird comes, the birds come; this is Isis with Nephthys. They have come seeking their brother Osiris...

There are truths preserved in the places they pass: recorded upon pyramids, tombs, temples, triumphant arches, statuary and churches. I look for him in the river and in the places he passed.

And I look up into the sky, where his soul became a star and see the birds circle wide and flaming around me before disappearing into His bright eye.

The monotonous, soothing desert nags my concentration. I do not like to step on Seth, 
who killed his father.

He disappears eventually, fades into another region, and Osiris reigns supreme. Dust and dry sand has given way to plump green trees, to shade, to laboriously worked areas where seeds might grow to adulthood before suffocation. Deserted estuaries and sand bars, meeting places for fish and birds, emerge before us like slow loops. Sometimes the river splits in two and curves around an island thick with figtrees and exhausted palms. Sometimes we float past villages where listless eyes widen at the sight of the glitter of our barge, its polish, its quiet, its lack of any function but pleasure.

I am glutted on light. Light above me, light below me, we are floating through Egypt on light.

My limbs cannot believe their lassitude, but in truth luxuriate in such inactivity after months of backbreaking, swift travel. To move through a place with such little effort. I am not sure I deserve this.

But I will earn it.

This barge is even aglow at night, when the sky is black and thick with pin pricks.

Orion shines on us. I read: Orion is Osiris' star.

There is a chandelier in the dining room, which sways and glitters with each gentle wave. Red lights dance off the silver, reflecting the blood red cushions. Blue lights scatter in the face of fluttering silk. Yellow light refracts into silver goblets from the moon.

This is not a place for our English God. He would be blinded by such brightness. He would cough into his clergyman's collar and sip his tea with averted eyes.

This place is someone else's domain, someone I haven't yet met.

We are treated like princes, surrounded by servants as smooth as snakes, who wear white gloves and expressive eyes that will not look into mine. Sir Toby and I have become actors in a theatrical troupe whose speciality is the reenactment of ancient luxury. We pretend we are accustomed to such extravagance. I, at least, am not. My masquerade forces an hilarity from me, that has a tendency to land in chilled soup. Sir Toby chides me, with a tired voice.

Do not laugh so, Isaac, they will think you mock them.

I mock no one but unbelievers, Sir Toby I reply, then stifle my laughter again.

Sir Toby I continue, what do you believe in?

Poor Sir Toby looks at me, sighs, continues drinking his soup and starts to read the book he has so pointedly propped up against the salt canister.

I do believe he would hire a translator and hang the expense if only he could find one that spoke my language.

I drink my soup and attempt to remain quiet, but find it hard to suppress the feelings that continuously erupt from me.

Our beds are enormous and covered in silk mosaic. The night air is fresh and cool with flower blooms. The air sucks dry any attempt at conversation. At night we anchor, as the waters are too perilous with sand banks to continue our journey in the dark. Apparently no one can see the danger that lurks beneath the black water. No one.

Some of the servants sit around a small fire on the shore, guarding us from bandits or beasts. Which is it? Who knows? No one tells us, no one speaks frankly to us.

I long for a fellow human being to look me in the face, as an equal. Here I am above or below. It is lonely.

My family have become as faint to me as apparitions. They are my blood, but even bloodstains fade. 
The sound of laughing servants mocks the lack of joy between Sir Toby and myself. I will no longer speak about nothing with him. My life is too short for such exchanges. I find it much more interesting to watch the dark river and to wonder about what lies beyond it.

To be warmed by the light of distant Orion.

Invisible dogs make the nights hideous with their howls.

In the mornings swimming children paddle near our barge and beg baksheesh from us. Others flick switches and drive indolent buffalo towards the water to drink. Some attempt to come aboard but our servants swiftly expel them. I saw a small brown hand clutch the railing I have clutched so many times, and then witnessed a servant, supposedly in our employ, hit that same small hand with a stick. The hand disappeared but happily not the child, who swam howling to the shore.

Women wash clothes on the riverbank with the restraint of moths. These women are such that the Masters would gladly have used for models. They disorientate me. They make me forget whether I am in a picture or observing one. It is not an altogether unpleasant disorientation.

Camels mumble deep into the water. Trees bend their lovely arms towards us, across the river's broad back.

Sir Toby is almost always writing but has adopted a new, irritating habit. He drums and rolls his fingertips on tables or his thighs when he writes, and the sound is amplified in my head until I must beg him to stop. But as I am now apparently officially ill, he excuses my irritability and tries to talk to me in the soothing tones of an ancient nanny talking to the idiot offspring of a suburban doctor.

I turn from him in disgust. Poor Sir Toby. My indifferent attempts to communicate with him have become as transparent, as feeble as the wings of a dying mosquito.

\section{Where Do Pictures Go if They are Not Born?}

We drift down this eternal river as if it will never reach the sea, which has become something as unimaginable as cool skin or walking on the moon.

My hands are as listless as my mind is overextended. I cannot draw. A pencil would be far too heavy for the frailty that permeates every inch of my poor fingers, those narrow brown things that dangle from my palms and have such import in the translation of the images in my mind. I wonder what I would do if I were to lose them. If some devil were to sever them and toss them away. Would my toes adapt to holding the brush? My mouth? Would I become a writer in images, a madman? But what would happen to all of the images imprisoned in my mind? Where would they go? Would people be able to see stories in my eyes? The world must be full of the ghosts of restless, unborn pictures, the ones that lived in dreams and eyes but were never realised in their material form. The very air must be a museum to such frustration. I have tried to grab the invisible shapes that crowd my head and wonder if I could hold in my head and heart the images born of artists long dead? Could my body become the conduit for their aborted visions? And what of such an eventuality in reverse? Could another artist paint the pictures that live on only in my head and not on my canvas? In case of such an eventuality, I am insisting of my memory that it become the artist. It must paint the pictures in the air, and claim authorship at once. I will not be thieved by spirits. I am resolute on this. 


\section{Almost Christmas}

It is almost Christmas, but sand and water have supplanted the snow of Sussex Street. But what water this is, water that changes its mind and colour at every river bend.

What is it? A home for birds or people? A drink for a thirsty field? A black line built to dissect sand?

It is an infinite story that refuses to reveal its purpose.

I do not recall such complex rivers at home.

My brothers and sisters would have chosen their tree by now and would have become once again accustomed to the fog and damp of a London winter.

I have not heard a word from them for so long I struggle to recall the features of their faces, which I know, as they are young, will have already changed. The feelings they engender in me are solid, but in the way a mud hut that is too wet is solid. Their details are becoming lost to me.

I weep when I think of their sweetness. They are too good for their brother Isaac who has become so full of images he cannot see a single picture.

I am tormented with loneliness.

\section{We go ashore}

Our boat is docked at Siut and we go ashore to visit the bazaar.

I wander away from Sir Toby and revel in the lack of his proximity.

There are wonderful things on offer here. Carpets, shawls and draperies of every colour and cloth, stagnant perfumes in strangely shaped and tinted bottles, the vermilion and primrose of countless Turkish slippers, local pottery, covered in wild red and black patterns. I would bet that anything could be bought here. I have spied second rate German cigars, spectacles from Paris and cloth from Manchester. The distance these objects have covered!

It is enough to boggle the mind.

Turks in light dresses, and large white turbans stroll about like sedate statues while Bedouin Arabs as dignified as Gods canter down the narrow streets on delicate ponies.

I am filled with a wild desire. I wish I had been born a blackguard, a robbing mountaineer, or a minstrel, so I could escape into the hills and live a life more adventurous than the one that awaits me on my return.

I could have a wife with golden piastres on her forehead. I would live with her in a small hut, filled with rugs and jewels, and she would love me, and never speak. We would never learn each other's language.

We would speak only with eyes and touch.

She would collect water from a well, and every day I would witness it.

Her silence would be her wedding gift to me.

Mine to her would be my protection, and my love.

My future stretches before me and the thought of it does not fill me with anything even approaching the emotions that the wild sounds of the tabar inspire in my soul.

I let music wash through me until I am suffused with a blissful delirium.

I find a step on which to sit and sketch. For once no-one takes notice of me. My hands fly over the page and images appear both before me and beneath my hand: the strange dress of street musicians, the bubbling water fountain in the middle of this delicious square, the 
generous trees, the dazzling dresses of sloe-eyed women, the stately dance of camels.

I lay my reason before this place. I give it my gift of line.

If only I had a friend who could hold me tight. These feelings are too big in me, too big for my body. Thoughts are generated in me I do not understand.

I hold my face to the sky and the heat makes me happy.

The Sun

The sun bounces off the stone on the riverbank. It forms balls of light that spin and surprise as they race and leap towards me.

I read that in many Ancient languages, the meaning of the eye and the meaning of the sun are expressed in the same word.

I read that the sun was named Osiris; giver of life, bestower of blessings, just judge, blessed and condemned, inspector, moderator, star guider, soul of the world, governor of nature.

I read that Osiris is described as the son of man.

How many sons of men can exist on earth? Men give birth to men and men then kill men.

It is endless, although being simply a son of one man has begun to feel equally bewildering.

I look from my eye and penetrate the sun with my gaze. My eyes, my own two suns.

The suns of one man.

This sun, of course, is yellow, as light tends to be, yellow and white but filled with other colour as well. Colour I could only describe with crude approximation if you were to ask, but colour nonetheless, and it is the colour of this world and the other one, for which I do not yet have a name. Perhaps it is mainly blue. Perhaps it was born in tones of brown, or even a cornflower, an iris, a sunflower, a child's bright ball.

When Sophia was a child, my father asked her, Sophia, what is you favourite colour, and without hesitation, she answered:

Father, my favourite colour is a rainbow.

An old sun-kissed branch. A bleached shard of bone. The golden heart of a daisy, dressed in its white skirt. It bounces back and forth, so full of rhythm and light, it makes me laugh.

I had never before noticed how well our largest star dances for us.

Sir Toby repeats like an old bore, his voice rising with every syllable

Isaac you are sun struck, you must stay indoors. I must insist that you not sit in this glare, in this heat.

I ignore his bumblings and hold my face up to the sky.

Struck by the sun. Such an idea, a fist of heat. Sir Toby cannot recognise his own poetry.

A delightful, clean hammer. A glorious fate. A blade of light, softened with mezzotint. As good, and as versatile as a knife that can slice butter and cut loose a noose.

Occasionally, I hide the joy of my discovery from him and surrender, falsely, to his solicitude.

Cool towels on my forehead, and my cabin is dark even in daylight. A boy with evasive eyes brings me tea, weak with lemon and too much sugar. Wafers, cold soup, dry bread. Occasionally a fig, but only if Sir Toby believes my nerves are up to accommodating its sweetness. 
I chew voraciously. In truth, I have never felt better.

\section{Banishing Sunlight}

I agree, with a voice so full of deceit I am astonished the world does not toss me overboard, with Sir Toby' refusal to allow that which I most welcome into my domain. He comes into my cabin, uninvited and banishes the sunlight with a lumbering hand. He inspires a silence in me, a tightness in my heart despite his generosity. He is too easy to watch. He leaves himself as open as a discarded novel, but quite despite his incessant commentary, cannot see a thing. He is so rarely aware of what is actually happening around him, I wonder at his thirst for travel. He is a man who believes himself so literate with the visual world, but I do not believe he has ever looked at his own shadow.

Sir Toby, I resist shouting without looking down, describe the colour of your shirt.

I would bet my boots he could not. He is not a man, for all his travelling, who ever looks.

He is round and full of himself, not unlike the sun, but definitely darker for all his cheer. I am, it is said, indebted to him, and with this I do not quarrel. He has brought me here, and quite despite himself, has revealed this place to me.

It is time now to leave. We begin our slow trail home.

Home. It has become a curious word to me.

\section{The Return}

Now, slowly, we travel back to England.

It is time, according to my mentor, to go home.

The boat moves slowly, arguing with waves, ceaselessly groaning with the effort of its passage. foulness.

The air is already cold, the sky more brittle, the food more foul and familiar in its

I refuse to sleep in a cabin with Sir Toby, and he has, so far, resisted persuading me otherwise.

When I am not keeping watch over my travelling companion, I wander the decks examining the heavens and reassuring stars. The moon slides slowly beneath clouds and mesmerises me. When not walking, I sit still and watch the light on the ocean, drinking ale after ale to keep me awake. Occasionally fish leap high above the water, and then, in a flash of silver, disappear beneath the glittering surface of their world.

Is the world smaller or bigger if observed through the eye of a fish? Is size dependent on the viewer or what is being viewed?

I do not know.

My mind's eye is preoccupied with things not human, and my heart is full of terrible knowledge.

I am certain. However far-fetched it may sound, Sir Toby, despite his innocuous appearance, is wrong in every decision he has ever made.

I observe him, and wish, no, long for the possibility that what I have seen in his company is simply a story that could be flung aside. What a blessing that would be. If only simple stories surrounded me.

But nothing I have seen or learnt is a story. They are ideas as tough and tangible as skulls.

A steward interrupts my watch with a falsely solicitous smile.

I grip my hands in my lap. I am so disgusted by this man's simpering manner I can 
hardly look at him.

I shout at him, bring me more ale. I must speak loudly to such fools so they can hear me.

They would not know the difference between a murder or an act of kindness.

They would not know what they had been given if pearls were poured on their eyelids.

The steward is too stupid to understand my communication, and looks at me so strangely it takes all of my will power not to throttle him for his impudent staring eyes. But I know, if I am to make headway, that I must learn to be more generous, more subtle than this. He does not know in what danger he has placed himself by working on board such a vessel, one whose cargo of flesh is so thoroughly rotten.

He scuttles off on his foolish indignant legs, and I resume my watchfulness.

The moon has nudged itself closer to its destination.

My ale is brought to me, with a sniff and a stiff back.

It tastes of salt.

I would that I could swallow stars that would shoot me into the sky and let me float above all of this, but I cannot, and so have no choice in the matter.

However flimsy the attempt, I must try to protect whatever innocence there may be on board this vessel. Perhaps there is a child asleep somewhere. God forbid. A child on such a boat is like a piece of steak before a starving man. Who will protect that child if I do not keep watch?

Sir Toby sits, laughing comfortably, with others who must be equally corrupt or doubly stupid. He brazenly shuffles and spreads his cards as he smokes and drinks and allows his eyes to roll around his head without settling once, with honesty, on anything. He will no longer look at me. Perhaps there is hope for the man, as he is so obviously satiated with his own guilt. He drinks like someone in a desert. He smokes like a sickened chimney. He is so glad to be with his fellowmen, these men who would travel with him into the depths of innocent souls to see how much they could borrow for their soulcoffers.

He does not know how much I know.

He would frighten himself if he did.

He must not win this game.

I would warn the captain if I could, but sly Sir Toby has warned him first, I can see it in the kindly glances he throws in my direction, as if I were a stray who begged to taste an occasional scrap of humanity.

He still calls me sunstruck, but less constantly, and with, I think, less solicitousness.

The Captain believes Sir Toby, he believes in his title and his eggshell authority, he believes in his corpulence and his obese vowels and his plump, determined hands.

Poor Captain. He has no awareness of the danger into which he has placed himself by playing cards with Sir Toby. They pretend the stakes are nothing more than a round of drinks. It is quite possible that Sir Toby will drag the ship under with him on his way home into the bowels of the earth.

\section{Destroying the Mark of the Devil}

I cannot help the lifting of my hand when Sir Toby deals the cards. And I cannot help but feel the heat that touches my hand when it comes into contact with my forehead. And I cannot help it if I must then go to the looking glass to see what has caused such heat to come from my forehead. And should I not be then applauded for cutting away from my forehead 
what the devil has placed there?

He marked me at birth for observance and now the mark is gone.

I will not bear Sir Toby’ revulsion at the blood that pours from my skin. It is only blood, which is no less natural than air, and we walk through air every moment of our lives.

But of course Sir Toby is repulsed. I have cut away the birthmark with which the devil insisted on burning me when he fought against my arrival in the world.

My heart is happy, even if I know it is a brief happiness. I cannot feel my wound, because it is not, despite the blood, a wound.

It is a shield.

The agents of Sir Toby will have a harder time recognising me now.

The respite will be momentary, as I am perfectly aware that they will find a way of marking me again, but when that happens I will cut that mark away from me as well.

At least I have stopped them playing cards.

The Captain, and any children on board, are safe now, if only for a while.

Until we arrive, when they, like me, will be on their own.

\section{Paris}

The last stage of our travels.

It is only a relatively short journey home now, but I have become incapable of imagining what that destination means.

Is it somewhere I have come from, or somewhere I must now create?

It is all I can do to contain my fury without distraction, and if injury is to be prevented of someone whose name I cannot bring myself to utter, think of, or write, then I must leave. Without farewell. Without thanks, which would choke my throat with bile.

I am stuffed full of him. I cannot have another morsel of his presence, however small the bite.

For him to suggest, and in the most veiled and falsely solicitous terms, that I am unwell, that my mind has become unbalanced and over stimulated and that it should, forthwith, be seen to, that it is, in a word, me, who needs immediate expert care, would be laughable if it were not so wholly tragic that the world has become so skewed about who is, and who is not, of sound mind. For a man so ignorant, so pompous, so full of his own fictitious worth to tell me, in no uncertain terms, that he is better, more healthy, more able to navigate his way through the purely superficial realm he likes to call the present I cannot stomach. And so I will never see him again. Because if I were to see him, even for a moment, I would have to remove him from this world, because it is men like him who make this planet a darker, more dishonest, more corrupt place.

Our views are at such variance, it seems astonishing that we share the same human shape. He makes no allowances for me as I, time and again, have made for him.

Of course, he will feel injured, and believe himself unthanked for his generosity.

I would like an appropriate response to this hypocrisy burnt into his brain. It is not generosity that makes a man like him drag a man like me half way around the world. No, it is simply a less obvious form of selfishness and egotism than that which a more honest man would more plainly state. This man's selfishness is actually more corrupt than its less subtle manifestations. I ask, is it generous for a man to demand sycophantic praise? To demand thanks for something that will make no mark whatsoever on his wealth, but will inflate his supposed reputation for artistic philanthropy? To demand from others conversation that will simply serve to bolster his own non-existent or borrowed opinions? No, I will say it again, and again, shout if I have to. He is not generous. These are not actions for which any vaguely 
sane or sensitive person would be thankful.

He has done nothing but enraged me. The rage that grows from the realisation that all that is apparent is not necessarily written on the surface of things. But perhaps, on reflection, I should thank Sir Toby for one thing; namely, he has cleared the clutter of sentimentality from my heart as surely as if he had taken a broom to my soul.

I will return to London immediately and discover the truth.

It should not be difficult to find, to recognise.

I, the neophyte, shall see it written in the skies of heaven's face.

\section{Arrival, London 1843}

I ring the doorbell, a deep, soft sound that ricochets through the house. I hear its journey finishing deep in the kitchen, rattling the pots, where it rests.

The parlour windows are curtained thick and close against the night air. A sliver of light allows only a tantalising glimpse of the trapped warmth. An emaciated fog is guarded by a slice of moon.

The rain is born sharp and dies with the caress of a pauper's hand.

It is so long since my skin has been touched that the reiteration of its existence surprises me. The drops are cold, but not unfriendly, as if the air is awake and would will all to wake with it.

Rain always sounds like something else. My particular journey's end is serenaded thus: water pouring from the sky like the clapping of small hands.

It applauds itself into my eyes and down my face and into my mouth, which is open to the elements.

I do not have a hat, but am sure I did once.

I cannot remember where I left it.

I lick the water off my lips. It tastes, oddly, like me.

I hear the floor creak, a young voice call out, but I do not recognise its source.

A door slams.

Then, I hear my father's voice call out with irritation: why does no one answer the door? The sound of it slaps into me with a feeling that has lain dormant for so long, it takes me a moment to recognise it.

I do not hear anyone reply. I think I hear my father sigh in exasperation and fling a book on a table, but cannot be definite.

London is so quiet and cold. The carriages on Suffolk Street sound muffled.

Even cats shiver.

I did not hear a thing on my way here, but witnessed enough to satisfy my curiosity. I had forgotten the golden light of London houses, and how it spills across roads like hysterical watercolours. I had forgotten how the intimation of fire hovers at the edge of houses. I had forgotten how thickly and quickly the coal dust settles on a shirtsleeve, and how the trees twist and moan at their lack of warmth. I had forgotten that birds could look miserable. I had forgotten the armies of damp beggars, and the extent of their deprivation.

I had forgotten how foul the streets are, even when washed clean by the elements.

At the instant that I pull the bell, a fancy coach pursuing a pair of fine greys flies past at such a speed the details of its journey are indistinct. One of the horses cries out and stumbles. The coachman whips and curses it, his fury wrapped in cloth.

A woman's laughter erupts from nowhere.

The poor beast throws me a supplicating glance, and they are gone.

I utter a stern prayer on the poor animal's behalf. 
A man who would beat a horse is not worthy of the name of man.

My father opens the door. He has no knowledge of the date or time of my return.

Has it come to this, that my father should answer his own door?

Although I know it is dark, I do not realise I am in the shadows.

He looks about, perplexed. I am made suddenly aware of my invisibility, and emerge into the shining doorway and blink. He looks at me, calls out with a look of confusion, hello?, and then stops his words as suddenly as if someone had popped a cork in his throat.

His face crumples like a failed drawing.

I look at him. He does not look as he did a year earlier.

I have been gone a lifetime and become a ghost. Can he see me as I see him?

He runs his fingers through his hair and gazes at me, as if I am no longer me, but a stranger. Only then does he confirm that the reality of this apparition is me.

No. Oh, Isaac!

He wraps himself around my poor body, and holds me so tight that for a moment I forget to breathe. He moves my hand up and down like a woman desperate for water from a pump. I drop my suitcase onto the sidewalk and hear a corner shatter. My soft bag slides off my shoulders, pencils rattling, unheeded.

I arrive as laden as a mule and as willing.

I am undone.

You are so wet, my boy. My dear boy. My boy. I had no idea, why did you not contact us, and tell us of your arrival? warmth.

He talks to my hair and holds me close, as if he would banish the rain with his own

The darkness recedes for a moment. I am home. I am startled at the sound of a deep sob that I recognise, with surprise, as my own.

I force myself to pull away from the heat with the reluctance of a traveller leaving a fire on a wet night. I cannot look any longer into the face of this father of mine that has altered its shape in such subtle and strange ways.

The mouth, smaller. The eyes, less direct. The arms, larger.

While I am considering him, and he, me, as if from nowhere, for I did not hear them coming, all manner of arms reach out to touch me, surround me, hold me, imprison me. Faces like glowing saucers circle me like planets. Shining eyes bore into my own. My face is buried in sweet smelling-hair, and the voices of the girls toll high and joyful.

I taste tears on my lips. My knees wobble in exhaustion. I cannot feel my feet from the cold.

Names begin to attach to faces.

John Alfred, at least a league taller, his mouth still open, his eyes still gazing.

Isaac! he cries.

Arthur John, shaking my hand like a man, and, also like a man, unable to look into in my eyes.

Sarah, unaccountably weeping and holding her face in her handkerchief.

Isaac we did not know. We did not know where you were. I do not know who utters these words, but they affect me in a way I do not immediately understand.

Where am I? Where was I?

Jane, smiling and patting my arm, father laughing and crying and talking and asking questions to break a traveller's heart. Everyone throwing words at me, as if I were a dancer and their words, violets.

But beside us all, separate from the mayhem, a still, dark figure, twisting her hands, her 
face focussed on mine like a telescope on a star.

Oh Sophia.

She takes my hand simply in hers, and it sits there, quiet. It is so cool and thin I cannot recognise it.

Surely, when I left, she had the chubby fingers of a child.

She is silent, and stands with her head drooping. A still pool amidst a hurricane. She looks at me and speaks.

Isaac, come inside. It is raining.

Without another word, she leads me home, holding my hand so tightly I can feel every bone. She will not let me go.

\section{Grass}

Dim London rooms force me to walk in parks.

I walk between flowerbeds and beyond the silver ponds and through the long, thin grass, towards what? I do not know what, or who, I will meet, although feel clearly that I do know where I am going, despite my ignorance of my destination.

Trees move towards me slowly in the breeze.

Conversations crowd my mind.

Lucky birds float over my head.

I no longer know what is hidden, a fact that has ceased to worry me, for I do believe the world chooses well in what it lets me know.

I hold my face up to the sky and it falls towards me, relieved to find a friend.

Everything that exists whispers to me.

Our lives lack air. We spend too many hours indoors, our skin growing paler by the second, and then have the temerity to complain about eternity in a box.

I have begged my brothers and sisters to run through the rain, and embrace the cold wet air on their skin, but they turn away from me, their faces no longer the faces I knew, their voices the voices of others.

They long for stories of my travels, which I cannot supply.

Nothing happened to me that was a story.

They are too resistant to understanding how dearly I hold their wellbeing in my heart. They will not accept that stories no longer exist for me, that everything that fills the earth and sky exists for a reason. However, despite their unfamiliar appearances, the souls of my family are knit into my skin and into my heart, and keep me warm.

Why they resist my advice, I have yet to discover. But I will. It should not be difficult, simply a matter, as with all things, of observation.

But I do feel compelled, nonetheless, to ask in the strongest terms possible, what kind of a life it is when a man or a woman or a child is deprived access to the sky? What kind of a life is it when a man is starved of sun? What kind of an existence prostitutes goodness, and invites the devil to dinner?

We all wear black in our family now. Father says it facilitates the cleaning of coal dust off cloth, but in truth I feel it is because we are in mourning, constantly present at the wake of our dreams.

This sadness would be intolerable if I did not know that the sun is always present, even at night, somewhere.

The world is full to overflowing. 


\section{Nourishment}

I dreamt I ate an owl last night. Sliced.

It called to me, and shivered. Its feathers shone in the soft night light, and it called to me again, but I refused to listen to it and carved it so thin it was almost transparent.

It was served to me on a plate garnished with flowers. I do not remember who brought it to me.

A disgusting dream. I was glad, for once, to wake and indulge in the only meal I consider bearable.

After much experimentation I have narrowed it down to two delicious things, both enough to sustain a man, and both, in their own way, the correct ingredients for a truthseeking man to swallow.

I eat chicken eggs, and sip ale. A belly full of thwarted birth and bubbles! A mind tickled with hops!

A fine meal, a perfect meal, one impossible to finish even when the food has gone. There is nothing more perfect than a cold white egg. An object with no beginning, and no edge. An infinite thing, a pure thing.

Who could not be inspired to dream of warm golden fields and hot summer suns, eating eggs and drinking ale?

The hop-pickers fingers, flying brown and warm down the lines of hops, most decent of plants. A girl with red cheeks and clean hair, a basket on her arm, plucking eggs from the warmth of the nest, product of the kind chicken.

This is food and drink to nourish more than stomach.

A fine meal, a perfect meal, one impossible to finish even when the food has gone. Eggshells and amber glass pile up against the walls, still lives to digest even when the hunger has been satisfied.

Playthings for light, objects born again with every rare ray of sunshine.

Bottles guard the soft pink excesses of eggshells which decorate my rooms; air, however dim or sad, hits their curves with a variation my imagination never tires of.

My castle is growing from the safest and most mysterious of bricks.

\section{A Visit}

My friends no longer come to the rooms I have taken to escape the intolerable demands of my so-called family, and I do not ask them why, but I do not care, involved as I am in making my first painting since returning to England. I have concentrated on rendering a scene of a group of water-carriers on the shore at Fortuna, near Mount Carmel. I will call it Caravan Halted by the Seashore. To once again have the luxury of paint and canvas at my disposal gives me greater joy that I could have imagined. Creating this image has occupied my mind to the point of distraction.

Surprisingly, however, a girl calling herself my sister Sophia came through my door today, the words falling from her mouth as suddenly as her hat from her head, which she dropped without a glance on the floor.

It was a plain hat, and not bright.

At first I did not recognise her and looked at her face long and hard, to dissect her disguise.

She was at once as familiar to me as my own hands and a stranger. It was unnerving.

Without preamble she launched straight into what she had to say.

Isaac, please, I want you to listen to me. Are you listening, Isaac?

The girl was well informed. 
I looked over her head. My room was very still.

My sister (delivered sarcastically), there is no one else here I could possibly listen to but you.

I meant the observation lightly, as an acknowledgement of our mutual masquerade, but she did not seem to hear the humour in my voice. Her lips came together in a wrinkled worried line, while her eyes shone hard and false at my own.

She was dressed in blue, and was thin. Her eyes were strange, holes in her head.

Isaac, please. I want to talk with you quietly. I need you to listen to me. I need your full concentration.

She then began to pull her handkerchief to bits. It was a mesmerising sight. It is difficult to tear cloth, and requires much strength, but this girl did not look strong.

I refused, however, to be distracted by such petty details, and so, despite the destruction of her haberdashery, I stood my ground.

I told her that nothing she could say to me could possibly interest me.

Why should I rest in the middle of the day, when there are paintings to be made and thoughts to be thought?

People increasingly request the strangest things of me.

To know who to welcome into my home is becoming more and more fraught.

Suddenly weary, I decided to sit down, to lend a polite ear to her falsehoods, to understand their provenance all the more clearly. However, an abrupt hammering on the door startled me and so, like any man whose door is hammered upon, I leapt up, confused as to who the identity of the person might be.

The girl attempted to intercept my investigation, so I was forced to whisper my reproach as fiercely as a whisper will allow.

Girl, are you expecting someone? Did someone escort you here? I was convinced the hammering and this strange girl must somehow be linked. The coincidence was too great.

The thought must have frightened her, as her eyes filled with tears so bright her face was immediately covered in terrified diamonds.

Isaac, I'm sure it was only the footsteps of the lodger above. It is no one. It is nothing. There is no one at your door. They have left. Did you hear that, Isaac, the door has slammed downstairs. There is no one there.

So does a woman deliver her sentence of deceit! With a jewelled face and reassuring words! How could she pretend not to hear the person who hammered so cruelly on my door. And she, supposedly my sister, my kin, my protector.

Impostor.

I suddenly realised that I had been listening so intently for the entrance of this stranger at my door, whose presence was so demanding of my energy and concentration, that I did not, at first, register the meaning of what this Sophia was saying to me, but in a flash, it struck me as solidly as that unknown fist upon my door struck my eardrums.

She was trying to prevent me feeling what I know I have to feel. She would prefer I slept the sleep of the ignorant or intemperate than live as clearly as I can. She would prefer me docile to wise.

Despite my transparent disgust, she refused to be quiet. Words flew from her mouth like pistol-shots.

Isaac, lie down, please! I want to talk with you, quietly. You are tired and need to rest. I have bought you some food. I will prepare it for you. Rest, Isaac! Please, there is no one there!

She still spoke to me as if I were an invalid! Lie Down! Food! Rest!

Her hands took hold of my own and burnt me. I pulled them away. Her heat was infectious. 
Let me make you some tea. Please Isaac, some hot tea. Isaac, you have not been eating properly. You need to eat. I will feed you.

Tea! A dull brown drink for sickly throats! Food! Banish the thought. Stuff for gluttons.

I did not dignify either her question or her observation with a reply.

I am filled with a fuel that propels me through the world with more energy than I should ever have thought possible. As if it were I who needed rest or nourishment!

Her sly hands came towards me again in a terrible, untruthful gesture of reconciliation. They clearly were shaking.

I pushed her away and could not look in her diamond eyes lest the truth of her betrayal be too clear even for my compassion.

I spoke above her head, to the wall.

Tell me where my father is, and perhaps I will talk with you.

A shriek from her and then a fist rammed into her mouth.

She spoke through her fingers.

Isaac, you must stop this. Father is where he always is. At home. At work. With friends, all of whom you know.

She is such a liar it makes me breathless. I obviously cannot speak with her and so, instead, I looked from the window, up at the clouds whose shapes I endlessly play with in my minds eye. The transfigured sky thrusts ideas in my mind so constantly I have begun to think of it as my apprentice.

I had become absorbed in watching a baby emerge fully clothed from behind a storm cloud and could feel the sun struggling to push the blanketed clouds away from its radiance, when I was pulled back to earth by the girls howling, which I do believe she felt would convince me of her true identity. What comedy such deceit lends itself to. This actress playing my beloved sister had lost her lines! And who did she feel was best equipped to help her find them? Why, me! The situation was so absurd, all I could do was laugh and laugh, which, for reasons unknown to me, seemed to replenish the water supply of her tears.

Her strange duplicity might be beguiling if it weren't so repulsive.

I hold my knowledge close to my heart, as it is the only dagger I know that will protect me well. I have learnt to identify the real skin beneath the surface. Whoever this girl is, she will never know as much as me.

\section{The Beginnings of a Plan}

So, I must plan the most appropriate strategy for doing battle with the devil, with whom I will fight. Apathy is a powerful enemy. I will not be lulled into a false sense of security, even if he refuses to fight.

It is common knowledge that the devil can transform himself into any shape he wishes and is most enamoured of the ones we assume to be good. Some recent examples: I have witnessed teacups rattle with horror. I have seen the mouths of puppies froth. I have seen the eyes of children radiate a hot, hard wrong. I have seen my own family replaced by impostors, who I have been impelled to paint with their punishment meted out.

It has become increasingly apparent to me that the most evil of intentions can be hidden in the creases of the cup of a soft hand, in the vowels or syllables of a kind word, or in the faces of people we assume to love. After all, the devil follows the logic of men and who are we more likely to trust? The people we know, or strangers we pass on the street?

So, I have built a suit of armour tight around my heart, and will use only my head to judge the righteousness of a situation.

It is possible I shall not find any adversaries yet, but I do know they are there. The only information I am now lacking is their names, not necessarily the ones they utter as their own, 
but the ones that have labelled their hearts.

I will not be swayed by what is superficially familiar.

I will not be moved by soft tongues.

Oh, the joy, after travelling for so long, to know with certainty what is right and what is not, causes my heart to relax. I am, at last, arriving at the home I have built from my own bricks, and it is not the one I once knew.

It is apt that the only words I own to express this new state of affairs appear as drawings fine as cobwebs. However, I am doubly lucky that if my clarity falters, a host of advice will immediately, and generously un-summoned, pour into my mind and ears, sourced directly, I am convinced, from the pure intentions of Osiris himself. It is enough luck to make a man whistle in the dark.

\section{A Visit to a Doctor}

We walk so quickly down a crowded street I stumble like a hack with splinters.

The man calling himself my father would take me by the hand if I would allow it.

(Where is my father? Where has my father gone?)

However, my fingers resist, and curl into a tight fist, so he clings instead to my coat sleeve.

I attempt to shake him off, but he persists.

It is quite astonishingly irritating. An image occurs to me: a gnat on the back of an elephant.

I giggle.

Beads of sweat tremble on his upper lip. His eyes are quite unnaturally large, and focussed on some unseen point he insists we rush towards.

He has demanded I accompany him to visit a doctor, a Isaac Sutherland, and I, for one, am too curious about what it all means to refuse.

I do not understand this preoccupation of people, none of whom I know, with the state of my health. They are constantly knocking on my door, or feeling my head, or bringing me idiotic, supposedly tasty morsels of food, or lapsing, in the middle of dull conversations, into silences fraught with a meaning I cannot fathom.

I do not understand it, not in the least. I have never felt more powerful or well, and they treat me as if I were a sickly child knocking on the gates of heaven.

We hurry along a street I do not recognise, dodging faces I have never seen. Puffing, this father speaks to me in thin vowels, like a man with a dry mouth.

Isaac, he will help you. I promise you, Isaac, he is a good man. He is a modern man.

Ah, once again, the problem of the good man. The man the whole world might support, and in their ignorance, support wrongly.

Father, (oh words heavy with humour), Father, I cannot support you in your assumption. I do not know his heart. He does not know mine. How can a man help someone of whose heart he has no knowledge? And how can a man who has no knowledge of the helper's heart, accept such help? The conditions are unclear. No one in their right mind would accept them.

The man hurrying so quickly at my side throws his head back, follows the clouds with his eyes, and does not reply. He does, however, give his lips a little lick.

If his response accords me a certain amount of satisfaction I do no reveal it, but allow that his silence acknowledges my small victory.

A modern man! Oh, foolish man calling himself my father.

(Where is my father? Where has my father gone?)

This is not the way to endear this so-called doctor, to me. I want to shout, what was so failed in the ancients that needed to be substituted with such flimsy falsehoods? 
I cannot think of one instance that might justify such substitution. What is there in the modern world that did not exist in the ancient one? What, in heaven's name, was in need of improvement, apart from the ever-present fundamental of men learning to recognise the truth?

Nothing. Nothing has changed, but the design of clothes and bricks and paltry flesh.

And they, for one, are easy to discard.

\section{The End, Again.}

Sometimes it is appropriate to speak dishonestly, if only to lure the dishonest closer to the net of their maker, whose responsibility it will then be to cast a cleanliness around untruth.

This is a man I do not know, but who calls himself my father.

(Where is my father? Where has my father gone?)

I would give anything to have my real father back, but cannot find him until this charlatan is disposed of.

To build a new house you have to pull down the bricks of the old dwelling.

Sometimes the bricks shriek as they are torn down, but who would heed the cry of rotten bricks?

I cannot let such cries bleed into my brain and distort the truth, the truth that has solid, if seemingly invisible, foundations.

This man calling himself my father, he is not my father.

There is nothing to be done but to strip away the disguise he has so cunningly built, and so reveal the good, the clean, the real foundations of what we so easily call the truth.

And so I tell him I must speak with him, at a place we both know.

He has done his research well, and recognises the place I mention as one my father, my real father, would respond to.

I tell him that once there, I will explain my motivations.

I tell him I am nostalgic for my childhood. I inform him, in clear tones, that I will clarify for him the situations that I have immersed myself in, the ones that confuse him. I tell him that, once there, he will understand.

I tell him that in the pure country air, all will become clear.

I tell him that I need to escape the filth of London, if only for a night or two.

I tell him I need fresh air and clarity and communication.

I tell him I must unburden my mind.

I tell him I love him.

And so we travel to Cobham, site of childhood happiness.

We travel together, and laugh.

We move towards his destination and he is happy, believing us to be close.

He has become so happy his face softens at the edges.

He relaxes and links his arm through mine.

He thinks he has earned my trust.

When we arrive we are hungry from our travels.

We find beds for the night and stroll to The Ship Inn, where we eat our fill, and drink to ease our communication. Men laugh as they drink in the rich light.

I cannot hear their words but only see the shape of their mouths as they utter their meaningless sounds.

The sound of a cuckoo conveys more sense to me now.

Our bellies are full and warm and we grow quiet with indulgence. 
The father impostor stretches, yawns, smiles at me, suggests we should sleep, it is late.

I inform him that I would like to walk to places we once loved. I tell him the night air is a tonic. I suggest, gently, that a walk will help me rest, will calm my nerves.

He is generous and listens to my request, and so, into the night, we walk.

The sky, the air and the ground, all are dark and cold. The roads are empty.

Sleeping birds wake at our footsteps and cry out.

How can a bird know that the morning will come?

Words drop from our mouths, fade, and then stop.

I embrace the silence with a joyful heart.

This man beside me shivers and attempts to hide it. He wraps his coat around him, and ignorantly talks of tomorrow. He takes a large white handkerchief from his pocket and noisily blows his nose.

We walk towards water, which mirrors the moonlight.

He looks at me, and does not understand.

How could he?

Suddenly, and with immense clarity, I know the moment has come to act.

Everything in me converges.

And so I take my blade and without warning I strike him, to propel him towards his maker who knows more than I.

I am simply the messenger.

At first it is as if nothing has happened. Everything is still. The sky. Flesh. Mouths. I am all eyes. My hands are linked to my sight. My heart has disappeared.

The man is astonished. His mouth opens but he makes no sound. He stares at me with bewilderment and looks down. My eyes follow his hands that he presses to his side. Then he moans, but still, we do not move.

We are as expectant as men waiting for a train.

For a moment, his clothes are the same as they ever were, and then they are not. His dull black coat is suddenly stained with a wet dark brown.

I think of a newly painted door. Or mud.

The colour of his face is not as it was. It is very pale, yet hot.

He moans once more and looks at me with eyes that slowly slip.

His body falls to one side and then stumbles. I hold my arms out and hold him tight so he cannot leave.

For a few seconds we are quiet together.

He whispers, please Isaac.

He is so corrupted he does not comprehend the magnitude of his untruthfulness.

Then the stillness is no longer and I am filled with fury and my heart is back where it belongs. I plunge my good clean knife into this impostor's throat. He must not be allowed to breath a minute longer. His violent hands push me away then return to clutch at his neck.

My blade drags through his skin, which is thick and difficult to cut.

I summon all of my strength.

I pull the blade out and push it in again and again, and then slice this man from side to side.

His flesh creaks and splits. His skin bursts and then deflates. 
He has become something other than himself.

He makes noises that I have never heard before. Gargling like someone drowning, but still breathing.

I remember walking on beaches beneath the sun and crushing thin shells with my boots.

I remember a woman gutting fish and whistling.

I recall hot poultices exploding boils.

I remember my father.

The memory inspires my power and my fury. strength.

This man does not receive my message well and argues with all of his dwindling

His arms move up and down as they attempt to push me away. His fingers drum my face. His legs scrabble to escape and then crumple.

A bird shrieks, the water shimmers. Mud grips the soles of my boots and I slip but hold onto him all the more tightly.

He begs and begs. He bleeds, he shrieks. He faintly cries.

He chokes on my name like a spell that would save him.

And then he fades.

My hands are red, his face is red, the mud is red.

Everything sticks to everything else.

Skin separates skin.

Spittle hits my face, fingernails have torn my flesh.

I too am bleeding.

It is distasteful.

Why should a man struggle at such a simple introduction to his maker?

I strip the mask from his throat and eyes and then finally he is peaceful.

The confusion in his eyes has gone forever.

From this moment on they will never deceive another soul.

He has departed into a hell of his own making and the person I once was has died.

And so, it also time for me to leave, but to a different destination.

I move towards the light.

It is time to find my father. 


\section{Broadmoor Hospital 1885}

All men live in shells yet dead souls float upwards, into the light.

It is so much more difficult to live than to die.

I will welcome the weightlessness of death, when the time comes for it to claim me.

I believe it will be soon.

My father has never visited me here, except when I sleep.

Occasionally I wake with the imprint of his warm hand on my brow.

Sophia has long gone. My sister refused to understand what it was I had to do, even though she, too, was impersonated.

My brothers, my sisters, my family have forsaken me.

God knows where they are.

Without the consolation of spirits I would be no one. lost souls.

My one responsibility here has been to paint the visitations of beings whose role it is to supply solace to

I have been obliged to reveal the tangled meaning of surfaces.

I have clarified distant memories of travelling through heat, escorted by the sun.

I have spent many hours exploring the complex exterior of leaves, and the reflections that inhabit the heart of water. respite.

I have painted the important marriages of mythology and the underworld souls who have lent me such

I have painted portraits of my friends.

I have painted the world that lives inside this one.

My brush is never still.

My pencil flies over paper on a journey more infinite than any I have ever taken.

Paint has become my canopy.

I will be joining my father soon and the thought of it fills me with me joy. I do not know where it was he went, but am sure I will be able to find him. We will exist in harmony, I have no doubt about that. We will become members of a great community of souls enclosed in walls of air and comforted by the sun.

I know my father will be the first to thank me for liberating him from that impostor.

In all modesty, if will be good, finally, to be thanked.

But sometimes when I wake, I wonder, where did I come from to arrive at this place? A hospital. A place for the sick, yet I have never had a single day of illness in my life. My flesh, perhaps, has been weak, but my soul overflows with rude good health.

It rains so much my bones are damp and will not dry.

When I die once more, my bones will dry in light.

Perhaps the story chooses the man and wraps him in it until he suffocates.

For me, the sun made up my mind, and the sun became my story.

But what of before?

Sometimes when I wake, I wonder, from where did I come to arrive at this place? 